\title{
Bank asset reallocation and sovereign debt
}

\author{
Michele Fratianni* and Francesco Marchionne**
}

\begin{abstract}
$\underline{\text { Abstract }}$
This paper examines how banks around the world have resized and reallocated their earning assets in response to the subprime and sovereign debt crises. We focus especially on the interaction between sovereign debt and the bank asset allocation process. After the crisis we observe a general substitution away from loans and in favor of securities. Our econometric findings corroborate that banks have readjusted the composition of their assets and the overall regulatory credit risk by substituting securities for loans. Banks, furthermore, have also been sensitive to those variables that are of direct interest to the regulator. The picture that emerges is a mutual protection pact regime, in which high-debt governments exert pressure on banks-either through the regulatory system or through moral suasion-- to privilege the purchase of government securities over credit to the private sector in exchange for receiving protection against default.
\end{abstract}

Key words: crisis, loans, regulator, securities, mutual protection pact JEL Classification: G01, G11, G21, G28.

\footnotetext{
* Indiana University, Kelley School of Business, Bloomington, Indiana 47405, USA; Università Politecnica delle Marche, Ancona (Italy; Money and Finance Research Group (MoFiR); fratiann@indiana.edu

** Nottingham Trent University, Nottingham Business School, NG1 4BU, Nottingham, UK; Money and Finance Research Group (MoFiR); francesco.marchionne@ntu.ac.uk.
}

Acknowledgement: This paper was written while Marchionne was a Visiting Fellow at the Indiana University Kelley School of Business; thanks are expressed to the hosting institution. 


\section{INTRODUCTION}

This paper examines how banks around the world have resized and reallocated their earning assets in response to the subprime and sovereign debt crises. In particular, we focus on the interaction between sovereign debt and bank asset allocation process.

The first impact of the subprime financial crisis occurred through the re-pricing of risk across a variety of assets and the shrinking of balance sheets. Recapitalization was aggressively pursued from the second half of 2007 through September 2008, when global banks raised $\$ 430$ billion of fresh capital (IMF 2008: 22). Then, recapitalization became increasingly costly, and leverage was effected by selling assets in illiquid markets. ${ }^{1}$ Thus, in the absence of fresh capital and without significant profits to retire debt in the short run, the de-leveraging process necessarily implied distress sales and falling asset values (Adrian and Shin 2008, Figure 2.5). The rapidly rising risk aversion of the public, fed by bad news and the thick fog of asymmetric information, pushed financial institutions to compress leverage quickly. According to Kollmann (2013), during the 2007-09 recession banking shocks accounted for about 15 percent of the fall in the US and the Eurozone GDP. The failure of Lehman Brothers on September 15, 2008 prompted governments to implement vast and costly rescue operations of their banking system (Fratianni and Marchionne 2013). Banks that received government assistance bought valuable time to restructure. Banks that did not receive assistance had to adjust more quickly.

Bank bailouts shifted risk from banks to governments (Acharya et al. 2014; Hryckiewicz 2014). ${ }^{2}$ The sovereign debt crisis of 2010 in the Eurozone and the consequent rise in spreads of government yields in the Southern countries relative to Germany's provided undercapitalized banks an opportunity to engage in gamble-for-resurrection strategies.

\footnotetext{
${ }^{1}$ With higher information asymmetries due to the crisis, investors are more reluctant to invest in bank equities. On the other hand, government-funded rescue plans raise banks' appetite for risk. In sum, adverse selection and moral hazard work towards undercapitalization.

${ }^{2}$ For the countries of the Eurozone as a group, government gross debt rose from $€ 6,493$ billion in 2008 to $€ 9.119$ billion in 2013 (IMF, WEO database).
} 
Acharya and Steffen (2013) present evidence of this strategy in which liquid government securities receive a preferential treatment, relative to bank loans, in capital regulatory risk weights and in government guarantees that make them an ideal collateral to obtain cheap central-bank funding. This phenomenon found its zenith when the South of the Eurozone, facing a sudden stop and later a reversal in capital flows, became disconnected from the money market in the North of the Eurozone. ${ }^{3}$ The European Central Bank (ECB) launched in 2011 and 2012 two rounds of exceptional lending to banks at cheap rates to ease the fragmentation of the inter-bank market. ${ }^{4}$ The shift from bank loans to securities occurred with a home bias (Levy and Levy 2014, Popov and van Horen 2013). In an investigation of this bias, Battistini et al. (2013) suggest two non-traditional reasons for this phenomenon. The first is that high-risk governments may exert pressure on domestic banks to buy more government debt; this pressure is part of an implicit mutual protection pact between banks and the sovereign. The second is that domestic government securities are a better edge than foreign euro-denominated securities should the country re-introduce a national currency. Whether with or without a home bias, undercapitalized banks raise the share of their assets in securities at the expense of private-sector credit. The implication is a displacement of investments, as in the model by Broner et al (2013) where the sovereign, in turbulent times, issues high-interest rate debt that is so attractive to crowd out alternative forms of debt.

The nexus between banks and sovereign can generate negative feedbacks (vicious circles). The traditional view has it that a credit crunch worsens borrowers' prospect of repaying outstanding loans, making banks riskier and necessitating further de-leveraging and de-risking. A different explanation is offered by Angelini et al. (2014): "the risk of a government's insolvency is a factor that permeates the entire national economy and is

\footnotetext{
${ }^{3}$ On sudden stops of capital flows, see Merler and Pisani-Ferry (2012); on the underlying factors of rising spreads in the Eurozone, see Alessandrini et al. (2014).

${ }^{4}$ This exceptional form of lending is known as long-term refinancing operations which had a maturity of 3 years and carried an interest rate of one percent. $€ 489$ billion were utilized in December of 2011 and $€ 529$ billion in February of 2012. Italian banks absorbed $€ 281$ billion and Spanish banks $€ 365$ billion.
} 
transmitted to all of the country's private institutions, not just to the banks; second, that the recent expansion of banks' government securities portfolios is a consequence, not a cause, of the crisis..." (p. 28). Both interpretations predict a shift towards government securities in banks' portfolio during a sovereign debt crisis.

There are a few recent studies on this topic. Sandleris (2014) develops a theoretical model showing that sovereign defaults can lead to a decline in foreign and domestic credit to the domestic private sector, even if domestic agents do not hold sovereign debt; stronger domestic financial institutions can amplify this effect. Acharya et al. (2014) model and test a two-way feedback between sovereign risk and bank credit risk and obtain that the positive relationship between public debt-to-GDP ratios and sovereign CDS premia is larger in countries with pre-bailout highly stressed banking sectors and higher debt ratios. Using dynamic panel methods, Buch et al. (2010) show that banks' first reaction to a domestic shock is to reduce foreign assets. Adelino and Ferreira (2014) apply difference-in-difference analysis to test the effectiveness of ceiling policies on banks' holdings of sovereign debt set by credit rating agencies. The authors find that sovereign downgrades by the agencies lead to a reduction of 30 percent in loan amounts (and a 15-50 basis points increase in loan spreads) for those banks close to the ceiling. To be noted, these studies focus on sudden macro shocks, whereas we emphasize banks' continuous portfolio adjustment.

With this background, our paper focuses on the interaction between sovereign debt and bank asset allocation process during the period 2005-2012, eight years that include four pre-crisis years and four crisis years. Data before 2005 are incomplete and available only for a few countries; the same is true for data after 2012. Sovereign debt is a privileged asset in that it does not absorb capital, unlike loans to the private sector. It can also be easily sold in liquid markets and is highly collateralizable to obtain monetary base from the central bank. All of these characteristics are observable and known and stem in large part from the 
financial regulator (in essence either the government or the central bank) having set formal and observable rules. But the regulator also uses informal and unobservable rules in influencing banks' decisions concerning asset allocation. These rules respond to the trade-off the regulator faces between systemic risk reduction and public debt financing; and the intensity of the trade-off rises during a financial crisis. The value of sovereign debt as a proportion of national GDP is used as a proxy of the overall impact on the banking system of both observed and unobservable rules. Our empirical specification will test to what extent loans and securities behave as substitutes; whether the asset allocation process favors securities and the existence of a "mutual protection pact" between banks and government; and whether banks are sensitive to the observed variables that are of direct interest to the regulator.

Our findings show that banks can readjust the composition of their assets and the overall regulatory credit risk by substituting securities for loans, and are sensitive to the variables that are of direct interest to the regulator. These findings are also consistent with a mutual protection pact regime, in which high-debt governments exert pressure on banks (either through the regulatory system or through moral suasion) to privilege the purchase of government securities over credit to the private sector in exchange for protecting the banking system. The quality of our findings is strengthened by the large dataset we have used. While previous studies have focused on specific institutions, typically large banks, ours encompasses the universe of the available categories of banks; and to our knowledge, this is the first paper to do so.

The structure of the paper is as follows. Section II presents our empirical strategy and the testable hypotheses. Section III deals with data and descriptive statistics. Virtually all of our data come from Bankscope, which have a high proportion of missing values and outliers. Since these aspects tend to bias coefficients' estimates and generate unstable results, we have 
spent considerable resources in cleaning the data. We present and discuss our empirical findings in Section IV and their robustness in Section V. In recognition of the likelihood that our data-cleaning procedure might have not been able to eradicate completely the outlier problem, we also apply regression analyses that are robust to such anomaly. The last section of the paper sums up the salient findings, their policy implications and themes for future research.

\section{EMPIRICAL SPECIFICATION}

Our empirical approach consists of two simultaneous equations, one explaining gross loans and the other total securities. ${ }^{5}$ The specification captures demand conditions, supply constraints, and the influence of the country's bank regulator-supervisor (simply the regulator). Banks exploit market demand to seize profitable opportunities, but face supply constraints resulting from the limitations of their financial structure. The sensitivity of bank loans and securities to demand shocks is used as a measure of the bank's ability to seize market opportunities (Gomez Meja et al., 2007). In light of the fact that revenue-oriented strategies are inherently risky, the regulator sets rules to reduce systemic risk (for our purposes we concentrate on credit risk) and limit the degree of moral hazard. Rules can be formal and observable and/or informal and unobservable to the market. Capital requirements are an example of formal and observable rules: banks must adhere to keep a minimum ratio of bank capital to risk-weighted assets, where the weight is positive for bank loans and zero for government securities. The impact of bank inspections and moral suasion on banks' decisions are an example of an informal and unobservable interventions. During economic downturns, the regulator faces a trade-off between systemic risk reduction and public debt

\footnotetext{
5 The number of observations on holdings of government securities is approximately one half of the observations on holdings of total securities in Bankscope. Considering that on average government securities represent 44.34 percent share of total securities and that their correlation coefficient is 66.42 percent, we have used the latter as a proxy of the former.
} 
financing. While public debt is formally set to have a zero credit risk, in reality it is not. Aware of the difference between formal rules and markets' perception, the regulator can use moral suasion to induce banks to alter asset allocation in favor of securities, thus influencing the degree of moral hazard in banks. The regulator can also influence banks' decisions concerning de-leveraging and asset allocation by being tougher or easier during bank inspections. If he is tougher, he will force banks to make upward adjustments in nonperforming loans; the opposite is true if he is more tolerant. Either way, the regulator will affect bank profitability and the level of bank capital, and consequently banks' decisions on de-leveraging and asset allocation.

The structure of each equation is somewhat reminiscent of a Capital Asset Price Model (CAPM) used in the economics of industrial organization; see Bertrand et al. (2002) and Sraer and Thesmar (2007). ${ }^{6}$ There, the firm's sales growth rate depends on the industry's growth rate, firm-specific characteristics and country-specific characteristics. The demand of firm $i$ is proxied by industry's sales. This approach has two advantages. The first is a parsimonious use of data, as the demand is determined endogenously exploiting information provided by the dataset. It also reduces the difficulty of integrating alternative data sets with bank accounting data, in particular specific series like bank loans and securities. The second is that the model uses only current variables rather than current and lagged variables. With lagged variables one faces a higher risk of having missing values and ending up with a selection bias. In sum, our model specification is economical in the use of data and more efficient in handling datasets with many missing values.

We adapt the industrial organization framework to the banking sector in four ways. First, we replace firm's sales with bank's growth rate of loans, $L_{i}$, in equation (1) and bank's

\footnotetext{
${ }^{6}$ Bertrand et al. (2002) use variation in mean industry performance as a source of profit shocks in the single firm to trace the propagation of shocks through a business group. Sraer and Thesmar (2007) estimate a fixed effect model, where single firm sensitivity is identified by the correlation between the changes in $\log$ sales and log employment. In both the models, industry shocks provide an ideal candidate to measure firm sensitivity since they affect individual firms but are - to a large extent - beyond the control of individual firms.
} 
growth rate of securities, $S_{i}$, in equation (2). We expect a positive effect of the home country's bank loan growth rate, $L_{H}$, on $L_{i}$ and of the home country's securities growth rate, $S_{H}$, on $S_{i}$. Second, we consider the bank supply constraints: the growth rate of total assets, $A_{i}$, and the ratio of non-performing loans to total loans, $N_{i}$, reflecting cumulative past decisions made by the bank. Third, we add the ratio of government debt to GDP, $B_{H}$, as a measure of a financial constraint at the country level: this is the proxy of the overall impact that the regulator exercises on the banking system. Fourth, we employ a host of specific control variables, contained in vectors $X^{L}$ in (1) and $X^{S}$ in (2), which are potentially relevant on banks' decisions concerning bank loans and securities. Finally, $u_{i}$ and $v_{i}$ are idiosyncratic error terms. In algebraic terms, the model in linearized form is as follows:

$$
\begin{aligned}
& L_{i}=-\alpha_{0} S_{i}+\alpha_{1} L_{H}+\alpha_{2} A_{i}-\alpha_{3} B_{H}-\alpha_{4} N_{i}+\alpha_{5} X_{i}^{L}+u_{i}, \\
& S_{i}=-\beta_{0} L_{i}+\beta_{1} S_{H}+\beta_{2} A_{i}+\beta_{3} B_{H}+\beta_{4} N_{i}+\beta_{5} X_{i}^{S}+v_{i} .
\end{aligned}
$$

Coefficients are defined to be positive; so the directional impact of the RHS variable on the LHS is given by the sign preceding the coefficient. All variables are measured at time $t$, and the time subscript has been omitted for brevity. Equations (1) and (2) are interdependent by virtue of the cross-quantity effects: $S_{i}$ in (1) and $L_{i}$ in (2). Risk reduction can occur either by a decline of total assets, for a given equity value, or through asset allocation. The first strategy, de-leveraging, fixes the asset portfolio structure and reduces proportionally each kind of assets. It gives rise to a size effect (or income effect in consumer theory syntax) due to the reduction in bank total assets. The second strategy, de-risking, keeps constant the overall amount of total assets and reallocates the portfolio from risky to "safe" assets. In this case, we observe a substitution of securities for loans. As in consumer theory, the two 
strategies are complementary and any combination of size and substitution effects is empirically possible.

To reduce systemic risk, regulators set observable time-invariant rules (e.g., capital requirements) aimed at preventing bank insolvency. But, as we have noted, regulators also use discretionary power to enforce largely unobservable time-varying rules, which better exploit the changing trade-offs over the business cycle between bank credit growth and bank safety. We assume that banks adopt a pecking order when coping with a riskier environment, such as selling assets in preference of raising more costly capital (Hyun and Rhee 2011) and reallocating assets in preference of reducing total assets that would entail capital losses from the sale of illiquid assets. The higher flexibility of the reallocation strategy avoids the realization of losses while gambling for a resurrection of the market value of the unsold assets. On the other hand, a reallocation strategy is more complex and takes more time than a total asset reduction and may not be a viable option when the required risk reduction is intense and fast.

The regulator affects bank strategies through unobserved rules, a sort of latent variable in the model. We assume that the sovereign debt variable, $B_{H}$, is of direct concern to the regulator. By interacting $B_{H}$ with market demand, $L_{H}$, and the growth of total assets, $A_{i}$, we can infer the influence that regulator's informal rules exert on loan and securities growth rates; see the following two equations:

$$
\begin{gathered}
L_{i}=-\alpha_{0} S_{i}+\alpha_{1} L_{H}+\gamma_{1} L_{H} B_{H}+\alpha_{2} A_{i}+\phi_{1} A_{i} B_{H}-\alpha_{3} B_{H}-\alpha_{4} N_{i}+\alpha_{5} X_{i}^{L}+u_{i}, \\
S_{i}=-\beta_{0} L_{i}+\beta_{1} S_{H}+\lambda_{1} S_{H} B_{H}+\beta_{2} A_{i}+\mu_{1} A_{i} B_{H}+\beta_{3} B_{H}+\beta_{4} N_{i}+\beta_{5} X_{i}^{S}+v_{i} .
\end{gathered}
$$

\section{Hypotheses testing}


Using equations (1) and (2) we can test several hypotheses. The first is that loans and securities are not substitutable, namely $H 1_{0}:-\alpha_{0}=-\beta_{0}=0$, against the alternative that the equations are linked together, $H 1_{a}:-\alpha_{0}<0$ and $-\beta_{0}<0$. The second is that changes in total assets affect proportionally $L_{i}$ and $S_{i}$, namely that $H 2_{0}: \alpha_{2}=\beta_{2}=1$, against the alternative hypothesis that asset reallocation favors securities, i.e., $H 2_{a}: \alpha_{2}<\beta_{2}$. The third deals with the regulator and his potential influence on bank's decisions. Neutrality with respect to government debt implies $H 3_{0}:-\alpha_{3}=-\beta_{3}=0$, against the alternative of a mutual protection pact that implies instead an asset reallocation in favor of securities, $H 3_{a}:-\alpha_{3}<0$ and $-\beta_{3}>0$. Finally, we can test an additional hypothesis using equations (3) and (4). Banks are insensitive to the observed variables that are of direct interest to the regulator in the sense that changes in demand and in total assets do not interact with the sovereign debt variable, $H 4_{0}: \gamma_{1}=\phi_{1}=0$ and $\lambda_{1}=\mu_{1}=0$, against the alternative that the interaction is not zero. Table 1 summarizes our testable hypotheses.

[Insert Table 1 here]

\section{DATA AND DESCRIPTIVE STATISTICS}

Our data sources are Bankscope and the World Economic Outlook of the International Monetary Fund (IMF) covering the period from 2004 to 2012. From Bankscope we have obtained yearly consolidated accounting data for all financial institutions in 43 countries, 34 of which developed industrial countries (i.e., OECD countries) and nine developing countries. ${ }^{7}$ Several different financial statements may be available for a given bank in a given reporting period (e.g., subsidiaries, cross-border banks, etc.). This requires that rules must be

\footnotetext{
${ }^{7}$ The 34 OECD countries are: Australia, Austria, Belgium, Canada, Chile, Czech Republic, Denmark, Estonia, Finland, France, Germany, Greece, Hungary, Korea, Iceland, Ireland, Israel, Italy, Japan, Luxemburg, Mexico, Netherlands, New Zealand, Norway, Poland, Portugal, Slovakia, Slovenia, Spain, Sweden, Switzerland, Turkey, United Kingdom, and United States. The nine developing countries included in our sample are: Brazil, China, Hong Kong, India, Indonesia, Philippines, Russian Federation, Singapore, and Taiwan.
} 
defined for selecting and merging these statements to obtain a unique time series for each institution. ${ }^{8}$ Our initial dataset consists of 197,721 observations and 21,969 banks. The term "bank" include six types of financial institutions: bank holding and holding companies, commercial banks, cooperative banks, investment banks, real estate and mortgage banks, and savings banks. All of them hold loans and securities and can effect both a de-leveraging and de-risking strategy. The market growth rate of loans and securities was computed using all financial entities available in Bankscope, rather than the six categories of banks in our sample; this produces a measure of market changes that is independent (and unbiased) of the holder of loans and securities.

\section{$\underline{\text { Data treatment }}$}

The Bankscope data contain many outliers, not only in a statistical sense but also in an economic sense. The data need to be cleaned from these anomalies. Robust statistical methods that identify "outlyingness" relax the homogeneity assumption that all observations fit a given model. These methods, however, have not been widely adopted because the outlier identification is hidden within the black box of the estimation method. The metric of "outlyingness" is based on a measure of discrepancy from a specific model that fits the data. But, in a more realistic situation of multiple outliers the, "outlyingness" metric may be contaminated by an unidentified outlier; see Billor et al. (2000) for details. Thus, we take a different approach in cleaning the data; this approach consists of three steps.

In the first step, we identify multiple outliers using the BACON (blocked adaptive computationally efficient outlier nominators) algorithm proposed by Billor et al. (2000). This

\footnotetext{
${ }^{8}$ The primary statement is labelled "Institution" by Bankscope. In general, this is a consolidated statement $(\mathrm{C} 1$, $\mathrm{C} 2$ ), and only in the few cases where a bank does not publish annual reports on a consolidated basis we use an unconsolidated version (U1). Bankscope has six codes for consolidation (C2, C1, $\mathrm{C}^{*}$ and $\left.\mathrm{U} 2, \mathrm{U} 1, \mathrm{U}^{*}\right)$, where $\mathrm{C}$ indicates a consolidated and U denotes an unconsolidated statement. The extension " 2 " indicates that both a consolidated and an unconsolidated statement exist for a bank (codes C2 and U2) at some point of time. Accordingly, the codes $\mathrm{C} 1$ and $\mathrm{U} 1$ indicate that no companion statement exists. $\mathrm{C}^{*}$ and $\mathrm{U}^{*}$ indicate that additional statements have been filed. This leads to the following seniority ranking of statements filed (assuming that consolidated statements represent the most senior information available): $\mathrm{C} 2 \mathrm{IC} 1>\mathrm{C}^{*}>\mathrm{U} 1>\mathrm{U}^{*}>\mathrm{U} 2$.
} 
algorithm works with iterative estimates and starts with an initial basic subset of "clean" observations and strikes a balance "...between affine equivariance and robustness" (Billor et al 2000: 296). ${ }^{9}$ Unlike other approaches, this method identifies outliers hidden in the standard 95\% confidence interval. Furthermore, it is relatively insensitive to the starting point and detects multiple outliers with a modest computational cost (i.e., as low as four repetitions of the underlying fitting method). ${ }^{10}$ For these reasons, it is practical with our large dataset. Outliers detected by the BACON algorithm are treated as systematic errors and the record in which they appear is removed from the dataset because of the contamination risk of the outlier metric.

The second step deals with implausible negative items in the balance sheet (e.g., negative equity value and equity-to-total-assets ratios larger than 100 percent). We replace these anomalies with missing values under the assumption that those observations are idiosyncratic and do not cross correlate with other data entries for the same bank at a given time period. If they were correlated and thus systematic, we would have eliminated the entire record of bank $i$ at time $t$. Given that the NEG procedure removes only negative values, the treated distribution accentuates its right skewness, which, in turn, makes it necessary a further detection method to identify right-side outliers.

The third step treats extreme outliers defined as $x<Q 1-3 * I Q$ and $x>Q 1+3 *$ $I Q$, where $x$ is the treated variables, $Q 1=1^{\text {st }}$ quartile of the frequency distribution, $Q 3=3^{\text {rd }}$ quartile, and $I Q=$ inter-quartile difference. Given that most of our variables have a right-

\footnotetext{
${ }^{9}$ An estimator, $\mathrm{T}$, is affine equivariant if and only if $T(X A+b)=T(X) A+b$ for any vector $b$ and non-singular matrix $A$. Affine equivariance is a desirable but arduous property in the sense that a robust regression or the nomination of outliers should not depend on the location, scale, or orientation of the data. BACON selects a small subset of observations based on Mahalanobis distances (equivariance) or distances from coordinate-wise medians (robustness). Moving from this starting point, it identifies interactively new sets of central observations with similar mean and covariance matrix, drifting toward the center when the subset of observations is not near enough to the center of the non-outlying data. As the basic subset grows in size, its mean and covariance matrix become more stable, preserving the initial equivariance and robustness; for more details, see Billor et al. (2000).

${ }^{10}$ For multivariate data, BACON is computationally more efficient and more performing multiple outlier detection method than the brute-force search, minimum volume ellipsoid (Rousseeuw and van Zomeren 1990), minimum covariance determinant (Rousseeuw and van Driessen 1999), and their more recent improvements.
} 
skewed frequency distribution and our treatment of negative values, the inter-quartile difference range procedure (IQR) detects outliers on the right side of the distribution. Again, we consider anomalous values as idiosyncratic errors and in the data are replaced with missing values.

The three steps were first applied to the original variables in level and then to the computed rates of growth and ratios. The only exception is the negative-value correction for growth rates: in this case, the frequency distributions are normal and the inter-quartile differences impact symmetrically on both sides of the distribution.

The reader can find in the Appendix detailed information on data and their treatment: Table A.1 shows the list of variables, their description and sources; Tables A.2 and A.3 present the results from the treatment on the original variables in level and on the computed rates of growth and ratios, respectively. We recall that BACON removes the affected records from the dataset, whereas NEG and IQR replace data entries with missing values. The presence of outliers is evident from the range of the original variables shown in Table A.2 (column "Bankscope"). This is further evidenced in the box plots of Figure A.1. BACON detects 1,165 anomalous records. NEG and IRQ procedures identify a much higher number of outliers for all variables, in particular for our two variables of interest, gross loans $(10,344)$ and total securities $(11,841)$. The bank selection criterion reduces the sample by $15-20$ percent.

Figure 1 shows the impact of our cleaning procedure on the frequency distributions of three critical variables. Gross loans, total securities, and total assets expressed in growth rates resemble a normal distribution, except for evidence of leptokurtosis due to the presence of outliers. A flatter leptokurtic distribution implies a higher variance. The black line in the boxplots shows the range between the inner fences (i.e., between $Q 1-1.5 * I Q$ and $Q 3+$ $1.5 * I Q)$; the dark grey line the range between the outer fences (i.e., between $Q 1-3 * I Q$ 
and $Q 3+3 * I Q)$; and the light grey the range between the maximum and minimum points. The identification of severe outliers can be obtained by difference.

\section{[Insert Figure 1]}

To give a measure of the impact of the cleaning and selection process on growth rates and on ratios, consider that the maximum value of gross loans and total securities is $1,808,766$ and 60,486,568 percent, respectively, before the treatment and 81.76 and 134.57 percent after. The treatment reduces the number of observations considerably, in a range contained between 25 to 75 percent depending on the variable in question; see Appendix for more details.

\section{Descriptive statistics}

Panel A of Table 2 presents descriptive statistics after the cleaning procedure. ${ }^{11}$ Four points are worth making. The first is that our dataset consists of 20,236 banks, but we lose more than two thirds of the observations as missing values; as an example, out of potential 160,963 observations for gross loans 54,331 remain usable. The second is that the wide dispersion of these variables and the right-skewness of the frequency distributions (e.g. 2.44 for gross loans, 2.43 for total securities, and 2.46 for total assets) indicate a further potential problem with outliers. The third is that all variables are leptokurtic, in particular gross loans (8.89), total securities (8.69) and total assets (8.94). The evidence of leptokurtosis and skewness suggest the use of growth rates to handle normally distributed variables. Finally, dummy variables show that 59 percent of observations come from commercial banks and 43 percent from banks adopting a regulatory accounting standard. These statistics corroborate the prevailing view that the introduction of a new regulatory system during a financial crisis is relatively slow moving.

\footnotetext{
${ }^{11}$ Growth rates and computed ratios are not reported for brevity.
} 
[Insert Table 2 here]

Panel B of Table 2 presents descriptive statistics for the only country-level variable used in our study, the ratio of gross government debt to GDP ratio. ${ }^{12}$ Also this ratio shows wide dispersion, right-skewness and leptokurtosis. These statistical phenomena reflect, not only the mix of highly indebted developed countries with lowly indebted developing countries, but also the jump in the debt-to-GDP ratio that has occurred as a result of the last financial and sovereign debt crisis.

Figure 2 shows the movement over the sample period of three critical frequency distributions. For improved visual clarity, we plot the distribution in the pre-crisis year of 2005 , in the peak crisis year of 2008, and in the last available year of 2012. The leverage ratio at the world level rises until 2008 and declines during the crisis. ${ }^{13}$ But in Europe, one can identify an asymmetry between Northern EU countries (NEU) where the leverage ratio is continuously decreasing, and Southern EU countries (SEU) where it is increasing. ${ }^{14}$

In other words, the expected process of de-leveraging following a financial crisis did not occur in Southern Europe which was also hit by the sovereign debt crisis. The asymmetry between NEU and SEU is even sharper if we consider the relative movements of gross loans and securities. In SEU, the distribution of gross loans to total assets shifts sharply to the left after the crisis, whereas in NEU it goes in the opposite direction. As to the ratio of securities to total assets, there is a rightward shift in its distribution after 2008, especially in SEU. In sum, after the crisis we observe a general substitution away from loans and in favor of securities, substitution that is accompanied by a de-leveraging process at the world level and in the Northern European countries, but not in the Southern European countries. The latter were boosting their holdings of government debt at the expense of a significant reduction of

\footnotetext{
${ }^{12}$ The source of the data is the World Economic Outlook Database of the IMF.

${ }^{13}$ Leverage is defined as total assets over equity, which is the inverse of equity to total assets shown in Figure 2.

${ }^{14} \mathrm{NEU}=$ Austria, Belgium, Finland, France, Germany, Ireland, Luxembourg, Netherlands, Slovakia, and Slovenia; SEU = Greece, Italy, Portugal, Spain.
} 
credit to the private sector. This behavior was not only facilitating the absorption of government debt, but also reducing the overall regulatory credit risk.

[Insert Figure 2 here]

\section{MAIN EMPIRICAL FINDINGS}

In this section we present and discuss the results from the estimation of two different models: the "benchmark" Model 1, as described by equations (1)-(2); and the "interactive" Model 2 given by equations (3)-(4), where the debt-to-GDP ratio interacts with the asset demand variable and total assets. ${ }^{15}$ In Model 2, we also add the square of the debt-to-GDP ratio to avoid that the interaction term may capture potential non-linear debt effects. For each of the two models, we apply four different econometric methods. The first is a panel estimator with bank fixed effects to capture idiosyncratic institutional features. The second is a quantile regression on median to mitigate the noted outliers problem. The third is a quantile regression applied to the following reduced-form equations of system (1)-(2):

$$
\begin{aligned}
& L_{i}=\frac{\alpha_{1}}{\Delta} L_{H}-\frac{\alpha_{0} \beta_{1}}{\Delta} S_{H}+\frac{\alpha_{2}-\alpha_{0} \beta_{2}}{\Delta} A_{i}-\frac{\alpha_{3}+\alpha_{0} \beta_{3}}{\Delta} B_{H}-\frac{\alpha_{4}+\alpha_{0} \beta_{4}}{\Delta} N_{i}-\frac{\alpha_{5}}{\Delta} C_{i}-\frac{\alpha_{0} \beta_{5}}{\Delta} E_{i}+\gamma X_{i}+\varepsilon_{i} \\
& S_{i}=-\frac{\beta_{0} \alpha_{1}}{\Delta} L_{H}+\frac{\beta_{1}}{\Delta} S_{H}+\frac{\beta_{2}-\beta_{0} \alpha_{2}}{\Delta} A_{i}+\frac{\beta_{3}+\beta_{0} \alpha_{3}}{\Delta} B_{H}+\frac{\beta_{4}+\beta_{0} \alpha_{4}}{\Delta} N_{i}+\frac{\beta_{0} \alpha_{5}}{\Delta} C_{i}+\frac{\beta_{5}}{\Delta} E_{i}+\lambda X_{i}+\delta_{i}
\end{aligned}
$$

where:

$$
\Delta=1-\alpha_{0} \beta_{0}, \gamma X_{i}=\frac{\alpha_{5}}{\Delta} X_{i}^{L}-\frac{\alpha_{0} \beta_{5}}{\Delta} X_{i}^{S}, \varepsilon_{\mathrm{i}}=\frac{u_{i}-\alpha_{0} v_{i}}{\Delta}, \lambda X_{i}=-\frac{\beta_{0} \alpha_{5}}{\Delta} X_{i}^{L}+\frac{\beta_{5}}{\Delta} X_{i}^{S} \text { and } \delta_{i}=\frac{v_{i}-\beta_{0} u_{i}}{\Delta}
$$

\footnotetext{
${ }^{15}$ We do not add time dummies in the empirical specification because macro effects are captured by countryspecific market demand. Time dummies would raise statistically the $R^{2}$ of the regressions but not in a meaningful way.
} 
The fourth is the two-step instrumental variables (IV) technique (using method 3 as the first step) that controls for endogeneity in system (1)-(2).

The results of Model 1, the benchmark model, are shown in Table 3. The first two columns give the estimates of the panel regression with bank fixed effects (FE); the third and fourth columns the estimates of the quantile regressions in the form of least-absolute-value model (LAV); the fifth and sixth columns the LAV estimates for the two reduced-form equations; and the last two columns the IV estimates of equations (1)-(2). We have data on 5.824 banks for loans and 5,834 for securities and the number of observations ranges from 20,546 to 25,948 depending on the estimation method. We ran both random and fixed effects models but report only the latter based on the Hausman test; however, results are similar for the two models. Fixed effects capture differences not only among banks, but also among countries. $R^{2}$ is consistently higher for Loans than for Securities, which could reflect in part that total securities are a proxy of government securities.

As to the estimated coefficients, the elasticity of loans and securities to market demand $\left(Y_{H}\right)$ is positive and is consistent with a CAPM-type model. The relatively low estimated value of beta is due to the incomplete universe of banks (six types) we have drawn from Bankscope. Significantly negative coefficients for the cross-variable $\left(X_{i}\right)$ indicate a strong substitution effect between loans and securities; hence, $H 1_{0}$ is rejected. The elasticties relative to total assets $\left(A_{i}\right)$ reject also the null hypothesis $H 2_{0}$ that banks allocate $\mathrm{A}_{\mathrm{i}}$ proportionally between $L_{i}$ and $S_{i}$ : there is a preference for securities. The debt-to-GDP $\left(B_{H}\right)$ coefficient is negative on loans and positive on securities, rejecting hypothesis $H 3_{0}$ that banks are neutral with respect to government debt in favor of the alternative of a mutual protection pact between regulator and regulated banks. The coefficients of the ratio of non-performing loans to total assets $\left(N_{i}\right)$ mimic those of debt and reinforce the general pattern that the de- 
risking is achieved by substituting securities for loans. A credit squeeze on the private sector is the natural consequence of a financial crisis.

The next two columns of Table 3 show the estimates of the quantile regressions (LAV) that treat the problem of potential outliers. ${ }^{16}$ In this case, we could not use the far too numerous bank dummies, and replaced them with an assortment of dummies that tried to capture bank characteristics such as whether they were listed, their type of accounting standards, their type of specialization, as well as country dummies. All of these dummies are jointly and highly significant statistically. LAV regressions confirm the signs and economic impact of the FE regression coefficients, with two exceptions: the substitution effects are stronger and the non-performing loans ratio does not impact securities.

In the next two columns of the table we show the estimates of the reduced-form equations of $L_{i}$ and $S_{i}$. In addition to the exogenous variables appearing on the right-hand side of (5) and (6), we have added the four dummies that capture the bank characteristics noted in the previous paragraph. The cross demand variable $-S_{H}$ in (5) and $L_{H}$ in (6) - has a negative sign and is confirmed by the coefficient estimates of $X_{H}$. A one percent increase in the demand for loans raises $L_{i}$ by 0.115 percent and lowers $S_{i}$ by 0.077 percent, whereas a one percent increase in the demand for securities raises $S_{i}$ by 0.269 percent and lowers $L_{i}$ by 0.032 percent; hence, an equal one percent increase in the demand for loans and securities shifts banks' portfolio toward securities by 0.11 percent. On the other hand, an increase in total assets produces a slightly stronger response in $L_{i}$ than in $S_{i}$, in contrast to the FE estimates.

In the final two columns of the table, we present the IV regressions to correct for the endogeneity of $L_{i}$ and $S_{i}$ in systems (1)-(2) or (3)-(4). The instruments of IV include the exogenous variables of the reduced-form equations plus the growth rate of deposits, the ratio of liquid assets to total assets, the return on assets and the four bank-characteristic dummies;

\footnotetext{
${ }^{16}$ The presence of outliers could bias standard econometric approaches, particularly when there are, as in our case, many missing and misreported values.
} 
as such, the specification is in line with what we have done with FE and LAV. The difference between IV and FE, in addition to the endogeneity treatment, consists in the four bankcharacteristic dummies and country dummies in place of bank fixed effects. There is a strong similarity in the findings. In particular, there is confirmation that the substitution of securities for loans is approximately five times as strong as the substitution of loans for securities. This substitution pattern is reinforced by the stronger response of $S_{i}$ to $A_{i}$ relative to the response of $L_{i}$ to $A_{i}$. Finally, the biggest impact on asset reallocation originate from debt to GDP. By multiplying the coefficient by the average value of $B_{H}$, we obtain that over the entire period $B_{H}$ has reduced loans by 9.07 percentage points and raised securities by 9.76 percentage points, for a net reallocation effect towards securities of approximately 19 percentage points.

\section{[Insert Table 3 here]}

Table 4 shows the estimates of Model 2, which adds to the basic specification of Table 3 the interaction of the debt-to-GDP ratio with $Y_{H}$ and $A_{i}$, as well as the non-linearity in $B_{H}$. The interaction terms capture whether banks let variables of direct interest to the regulator react to the evolution of $B_{H}$. As we have done for previous hypotheses, we test that banks are insensitive to the regulator's concern $\left(\gamma_{1}=\phi_{1}=0\right.$ and $\left.\lambda_{1}=\mu_{1}=0\right)$ against the alternative that they are sensitive. The structure of Table 4 is similar to that of Table 3; estimates and test statistics are, on the whole, also similar. The important finding is that the interactive terms with $B_{H}$ are marginally significant: their impact is negative on loans in $\mathrm{FE}$ and LAV, positive on securities in LAV and IV, and insignificant in the reduced form equations. Thus, the null of $H 4$ is "weakly" rejected against the alternative that the existence of government debt raises the reaction of securities to market demand while lowering the reaction of loans; in essence, there is some evidence that the debt-to-GDP ratio tilts the allocation process towards securities, not only directly, but also indirectly through market demand and total assets growth. The other relevant results of Table 4 is that the statistically 
significant coefficient of $B^{2}{ }_{H}$ suggests the presence of threshold effects already emphasized in the literature; see, for example, Minea and Parent (2012), Checherita-Westphal and Rother (2012) and Law and Singh (2014). The novel aspect here is that the curvature for loans is different than that of securities (concave).

\section{[Insert Table 4 here]}

In the section on descriptive statistics we have shown that EU banks, largely in response to the sovereign debt crisis, appear to have accentuated their portfolio re-adjustment towards securities at the expense of credit to the private sector; and this pattern is particularly evident for banks in the Southern EU countries. ${ }^{17}$ Therefore, we would expect the EU-area sample estimates to differ from the world sample estimates in two significant ways: first, that aggregate demand in the EU area would provide a further bias towards $S_{i}$, and second that the debt-to-GDP ratio would have larger absolute impacts on $S_{i}$ and $L_{i}$. Table 5 confirms such prediction. An equal one percentage point increase in $Y_{H}$ in the two equations produces a larger shift towards securities in the EU estimates than in the world estimates. A similar finding holds for the debt-to-GDP. In sum, the security-bias in the portfolio reallocation for the entire sample is accentuated in the EU area.

\section{[Insert Table 5 here]}

\section{ROBUSTNESS}

To check the robustness of our results, we run four econometric exercises. The first is to measure the growth rate of market demand for loans and securities excluding bank $i$, that is the observation of the bank on the left-hand side of the regression, in sympathy with what is done in the industrial economics literature. The objective of this exercise is to check the market power, or potential bias, of a large bank in the computation of the aggregate demand variable. In a one-bank system, the left-hand side variable would be equal to $Y_{H}$; in a banking

\footnotetext{
${ }^{17}$ See the relative movements of gross loans and securities in Figure 2.
} 
system with a large number of equal-size banks, the left-hand side variable would have a negligible impact on the computation of $Y_{H}$; in the more realistic case of a banking system with a small number of big banks and a large number of small banks, the left-hand side variable would be quite sensitive to the inclusion of a large bank in the computation of $Y_{H}$. The first four columns of Table 6 (which shows for brevity only the benchmark FE and LAV estimates) use the narrow definition of market demand, $Y_{H-1}$, instead of the broad definition, $Y_{H}$. The $Y_{H-1}$ coefficients remain positive, although smaller in size and, in some cases, with lesser statistical significance than those of $Y_{H}$ in Table 3. In sum, this exercise, not surprisingly, confirms that most banking systems display some degree of market power; yet, our previous results hold.

The second exercise adds common and specific variables to the loans and securities equations to further reduce the risk of relevant omitted variables. In Table 6 it is labelled as Model 3: it extends the benchmark model of Table 3 with specific controls for loans and securities. These controls are the equity-to-total assets ratio, $E_{i}$, the loans-to-deposits coverage ratio, $C_{i}$, the growth rate of deposits, $D_{i}$, the ratio of liquid assets to total assets $\mathrm{Q}_{\mathrm{i}}$, and the average return on assets, $R_{i}$. Our rationale for choosing $E_{i}$ is that banks strive for an optimal financial structure and, consequently, $L_{i}$ and $S_{i}$ could be sensitive to the evolution of the current value of $E_{i}$ in relation to an optimal but unobserved value. $E_{i}$ is present in both equations. $C_{i}$ and $D_{i}$ are specific to the loan equations. Their justification are straightforward. Since deposits are a more stable source of funding than alternative liabilities, banks may seek to match deposits to long-term and unmarketable loans to reduce risk. Furthermore, a predictable growth of deposits would further reduce uncertainty given the very short-term maturity of deposits. $Q_{i}$ and $R_{i}$ are instead specific to the security equation. While liquidity in principle is a substitute for both loans and securities, we assume that the second substitution dominates the first, particularly during a credit crunch. $R_{i}$ is a broad measure of performance 
with a potential ambiguous effect on $S_{i}$. When loans' credit risk is perceived to be high relative to securities', we would expect that a rising $R_{i}$ would induce banks to favor securities in their allocation strategy. When credit risk is perceived to be high equally for both loans and securities, a rising $R_{i}$ would induce banks to privilege liquidity and $S_{i}$ would decline.

The explanatory power of Model 3 with the five controls just discussed rises relative to Model 2 estimates; see last four columns of Table 6. All the control variables are statistically significant, except for $E_{i}$ and $R_{i}$ in the LAV securities equation. $C_{i}$ and $D_{i}$ impact the loan equation positively, as expected. $Q_{i}$ and $R_{i}$ impact securities negatively and their sign pattern is consistent with the well-publicized rush for liquidity. Our main results remain unchanged.

\section{[Insert Table 6 here]}

The third exercise was to broaden the number of exogenous variables included in the second step of the IV regressions of Table 3. The added controls are of two types, macro and micro. The macro control consists of the country's economic growth (real GDP). The micro controls are the ratio of bank's total business to total assets, the number of banks under the same business group and the banks' net interest margin. The four controls are first entered one at a time and then as a group in Table $7 .^{18}$ There is a considerable degree of stability in the sign, size, statistical and economic significance of the estimated coefficients and in the explanatory power of the regressions across the table's columns, a reflection that the specification of the IV estimation of Table 3 remains robust to the four added macro and micro controls.

\section{[Insert Table 7 here]}

The fourth and final step was to test the IV regression of Table 3 for the crisis period 2009-2012. We do not report the actual estimates here to save space but discuss the salient

\footnotetext{
${ }^{18}$ We experimented with combinations of two and three controls with similar results. We don't report results for brevity.
} 
findings. The only material change in the loans equation in the crisis period affects the debtto-GDP ratio whose value drops to approximately one half of the coefficient's value for the entire period; the statistical significance remains the same, however. The material changes in the securities equation occur in the substitution effect and in the response to aggregate demand. The former goes from $-0.548 * * *$ to $-0.278 *$; the latter from $.224 *$ to $.547 * * *$. The implication is that during the crisis period banks have raised their allocation share in favor of securities to changes in aggregate demand, while lowering their securities sensitivity to the growth of loans. These patterns are what we would have expected and are in sympathy with one of the main results of our study: a deep financial crisis penalizes credit to the private sector.

\section{CONCLUSIONS}

This paper has examined how banks around the world have resized and reallocated their earning assets in response to the subprime and sovereign debt crises. We have focused especially on the interaction between sovereign debt and the bank asset allocation process. After the crisis we observe a general substitution away from loans and in favor of securities, substitution that was accompanied by a de-leveraging process at the world level and in the Northern European countries, but not in the Southern European countries. The latter were boosting their holdings of government debt at the expense of a significant reduction of credit to the private sector. Our econometric findings corroborate that banks have readjusted the composition of their assets and the overall regulatory credit risk by substituting securities for loans. Banks, furthermore, have also been sensitive to those variables that are of direct interest to the regulator.

The picture that emerges is a mutual protection pact regime, in which high-debt governments exert pressure on banks, through the formal and informal regulatory system, to 
privilege the purchase of government securities over credit to the private sector in exchange for receiving protection against default. The quality of our findings is strengthened by the large dataset we have used. While previous studies have focused on specific institutions, typically large banks, ours encompasses the universe of the available categories of banks; and to our knowledge, this is the first paper to do so.

As to specific hypotheses, we found strong substitution effects between loans and securities, with the substitution of securities for loans being approximately five times as strong as the substitution of loans for securities. This asymmetric pattern is reinforced by a larger elasticity of securities with respect to total assets than the corresponding loan elasticity. The debt-to-GDP coefficient has a negative impact on loans and positive on securities, rejecting the hypothesis that banks are neutral with respect to government debt in favor of the alternative of a "mutual protection pact" between regulator and regulated banks. The evolution of the debt-to-GDP ratio has the biggest impact on asset re-allocation. European Union banks have accentuated their portfolio readjustment towards securities at the expense of credit to the private sector. Finally, during the crisis period 2009-2012, banks have further raised their relative allocation share in favor of securities in response to changes in aggregate demand, while lowering their securities sensitivity to the growth of loans. These patterns are what we would have expected and are in sympathy with one of the main results of our study: a deep financial crisis penalizes credit to the private sector

Our evidence that banks have effected de-risking by substituting securities for loans reflects the Basel rule that government securities, a significant component of total securities, have been accorded the special status of having a zero weight in the computation of riskweighted assets. The noted substitution lowers regulatory risk but not necessarily true economic risk. The obvious policy recommendation would be to align regulatory risk to economic risk, so as to achieve portfolio allocations based on return-risk profiles without the 
murky considerations of moral hazard and mutual protection pacts. On the other hand, strict public-choice analysis suggests that such a change is not likely to occur.

As to plans for future research on the subject, we have two extensions in mind. The first is to focus on Eurozone banks and especially on the asymmetry between Northern and Southern regions with a longer and updated period. We expect that financially stressed Southern banks might have adopted more de-risking than de-leveraging to achieve relevant risk reductions, whereas the opposite might have occurred in Northern banks. The second is to examine in further detail how regulators impact on the asset allocation of bank portfolios through the use of risk-weighted assets instead of market measures.

\section{References}

Acharya, V.V., Steffen, S. (2013), The "greatest" carry trade ever? Understanding Eurozone bank risks, NBER, WP 19039.

Acharya, V.V., Drechsler, I., Schnabl, P. (2014), A Pyrrhic Victory? Bank Bailouts and Sovereign Credit Risk, Journal of Finance (forthcoming), DOI: 10.1111/jofi.12206

Adelino, M., Ferreira, M.A. (2014), Bank Ratings and Lending Supply: Evidence from Sovereign Downgrades, available at SSRN: $\underline{\text { http://ssrn.com/abstract=2376721 }}$

Adrian, T., Shin, H.S. (2008), Liquidity and leverage, Federal Reserve Bank of New York, available online at http://www.newyorkfed.org/research/staff reports/sr328.html.

Alessandrini, P., Fratianni, M., Hughes Hallett, A., Presbitero, A. (2014), External imbalances and fiscal fragility in the Euro area, Open Economies Review, 25: 3-34.

Angelini, P., Grande, G., Panetta, F. (2014), The negative feedback loop between banks and sovereigns, Banca d'Italia, WP 213, January 2014

Battistini, N., Pagano, M., Simonelli, S. (2013), Systemic risk and home bias in the Euro area, European Economy Working paper, February 6.

Bertrand M., Mehta P., Mullainathan S. (2002), Ferreting out tunnelling: an application to Indian business groups, Quarterly Journal of Economics, 117(1):121-148

Billor, N., Hadi, A.S., Velleman, P.F. (2000), BACON: Blocked adaptive computationally efficient outlier nominators, Computational Statistics \& Data Analysis, 34: 279-29.

Broner, F., Erce, A., Martin, A., Ventura, J. (2013), Sovereign debt markets in turbulent times: Creditor discrimination and crowding-out effects, NBER Working Paper No. 19676. 
Buch, C.M., Carstensen, K., Schertler, A. (2010), Macroeconomic Shocks and Banks' Foreign Assets, Journal of Money, Credit and Banking, 42(1):171-188

Checherita-Westphal, C., Rother, P (2012). The impact of high government debt on economic growth and its channels: An empirical investigation for the euro area, European Economic Review, 56(7):1392-1405.

Fratianni, M., Marchionne, F. (2013), The fading stock market response to announcements of bank bailouts, Journal of Financial Stability, 9: 69-89.

Gomez Mejia, L., Haynes, K.T., Nunez, M., Jacobson, K., Moyano, J. (2007), Socio-emotional wealth and business risk in family-controlled firms: evidence from Spanish olive market. Administrative Science Quarterly. Q. 52, 106-137.

Hyun, J.S., Rhee, B.K. (2011), Bank capital regulation and credit supply, Journal of Banking \& Finance, 35:323-330.

Hryckiewicz, A. (2014), What do we know about the impact of government interventions in the banking sector. An assessment of various bailout programs on bank behavior, Journal of International Financial Markets, Institutions and Money, 32:150-166

Kollmann, R. (2013), Global Banks, Financial Shocks, and International Business Cycles: Evidence from an Estimated Model, Journal of Money, Credit and Banking, 45(2):159-195

International Monetary Fund (online),World Economic Outlook Database; available at http://www.imf.org/external/pubs/ft/weo/2014/01/weodata/index.aspx

International Monetary Fund (2008), Global financial stability report: Financial stress and deleveraging, macrofinancial implications and policy, October 2008, Washington, DC.

Law, S.H., Singh, N. (2014), Does too much finance harm economic growth? Journal of Banking \& Finance, 41 (2014) 36-44

Levy, H., Levy, M. (2014), The home bias is here to stay, Journal of Banking \& Finance, 47:29-40

Merler, S., Pisani-Ferry, J. (2012), Sudden stops in the euro area, Review of Economics and Institutions, 3(3):Article 5.

Minea, A., Parent, A. (2012), Is high public debt always harmful to economic growth? Reinhart and Rogoff and some complex nonlinearities, Association Francaise de Cliometrie, WP 8.

Popov, A., van Horen, N. (2013). The impact of sovereign debt exposure on bank lending. Evidence from the European debt crisis, De Nederlandsche Bank Working Paper, No. 382

Rousseeuw, P.J., van Zomeren, B. (1990), Unmasking multivariate outliers and leverage points (with discussion), Journal of the American Statistical Association, 85:633-639.

Rousseeuw, P.J., van Driessen, K. (1999), A fast algorithm for the minimum covariance determinant estimator, Technometrics, 41:212-223.

Sraer D., Thesmar D. (2007), Performance and Behaviour of Family Firms: Evidence from the French Stock Market, Journal of the European Economic Association, 5(4):709-751 
Table 1: Summary of hypotheses testing

\begin{tabular}{|c|c|c|c|}
\hline HYP & Name & $\boldsymbol{H}_{\boldsymbol{0}}$ & $\boldsymbol{H}_{\boldsymbol{a}}$ \\
\hline 1 & Substitution effect & $-\alpha_{0}=-\beta_{0}=0$ & $-\alpha_{0}<0,-\beta_{0}<0$ \\
\hline 2 & Size effect & $\alpha_{2}=\beta_{2}=1$ & $\alpha_{2}<\beta_{2}$ \\
\hline 3 & Neutrality of the government & $-\alpha_{3}=-\beta_{3}=0$ & $-\alpha_{3}<0,-\beta_{3}>0$ \\
\hline 4 & Demand sensitivity to regulator & $\gamma_{1}=\phi_{1}=0$ & $\gamma_{1}, \phi_{1} \neq 0$ \\
\hline
\end{tabular}

NOTES: HYP = hypothesis number, $H_{0}=$ null hypothesis, $H_{a}=$ alternative hypothesis. Coefficients refer to equations (1)-(4).

Table 2: Descriptive statistics on cleaned Bankscope data

\begin{tabular}{lrrrrrrrr}
\multicolumn{1}{c}{ Variables } & Mean & St.Dev & Min & Median & Max & Nr.Obs. & Skew. & Kurt. \\
\hline PANEL A: Bank-level variables & & & & & & & & \\
\hline Gross Loans (th USD) & 889380 & 1351278 & 0.27 & 324127 & 7280833 & 54331 & 2.44 & 8.89 \\
Total Securities (th USD) & 311159 & 507139 & 0.03 & 91692 & 2631347 & 52720 & 2.43 & 8.69 \\
Total Assets (th USD) & 1691330 & 2631584 & 38.65 & 565254 & 13900000 & 55350 & 2.46 & 8.94 \\
Total Equity (th USD) & 137490 & 208641 & 7.7 & 49005 & 1093173 & 55491 & 2.43 & 8.78 \\
Total Deposits (th USD) & 963834 & 1435918 & 0.03 & 346714 & 7397910 & 52778 & 2.30 & 8.07 \\
Impaired Loans (th USD) & 40026 & 65885 & 0.07 & 9947 & 339115 & 32757 & 2.35 & 8.30 \\
Liquid Assets (th USD) & 223604 & 358711 & 1 & 63600 & 1893717 & 55121 & 2.42 & 8.70 \\
Coverage Ratio (\%) & 97.50 & 50.70188 & 0.01 & 87.60 & 311.56 & 52693 & 1.34 & 5.59 \\
Return on Assets (\%) & 0.62 & 0.82 & -2.63 & 0.43 & 3.98 & 58690 & 0.65 & 6.09 \\
Listed (dummy) & 0.07 & 0.25 & 0 & 0 & 1 & 160963 & 3.41 & 12.62 \\
Accounting & & & & & & & & \\
IFRS (dummy) & 0.08 & 0.27 & 0 & 0 & 1 & 160963 & 3.05 & 10.30 \\
Regulatory (dummy) & 0.43 & 0.50 & 0 & 0 & 1 & 160963 & 0.28 & 1.08 \\
GAAP (dummy) & 0.27 & 0.44 & 0 & 0 & 1 & 160963 & 1.02 & 2.05 \\
Specialization & & & & & & & & \\
Holding (dummy) & 0.14 & 0.34 & 0 & 0 & 1 & 160963 & 2.12 & 5.48 \\
Commercial (dummy) & 0.59 & 0.49 & 0 & 1 & 1 & 160963 & -0.36 & 1.13 \\
Cooperative (dummy) & 0.12 & 0.33 & 0 & 0 & 1 & 160963 & 2.28 & 6.20 \\
Investment (dummy) & 0.02 & 0.15 & 0 & 0 & 1 & 160963 & 6.50 & 43.26 \\
Real Estate (dummy) & 0.01 & 0.12 & 0 & 0 & 1 & 160963 & 8.08 & 66.36 \\
Saving (dummy) & 0.11 & 0.32 & 0 & 0 & 1 & 160963 & 2.412 & 6.85 \\
\hline PANEL B: Country-level variables & & & & & & & & \\
\hline Debt-to-GDP ratio (\%) & 56.61 & 37.65 & 3.68 & 47.50 & 238.02 & 344 & 1.67 & 7.58 \\
\hline
\end{tabular}

NOTES: Period: 2005-2012. We use 2004 to compute growth rate (see other tables). Total observations: 160,963. Number of banks: 20,236. 
Table 3: Model 1; panel regressions (Bank FE), quantile regressions (median LAV) and instrumental variables (IV)

\begin{tabular}{|c|c|c|c|c|c|c|c|c|}
\hline \multirow[b]{3}{*}{ Variables } & \multicolumn{8}{|c|}{ Model 1} \\
\hline & \multicolumn{2}{|c|}{$F E$} & \multicolumn{2}{|c|}{$L A V$} & \multicolumn{2}{|c|}{ LAV - Reduced Form } & \multicolumn{2}{|c|}{$I V$} \\
\hline & $\begin{array}{c}\text { Loans } \\
(1) \\
\end{array}$ & $\begin{array}{c}\text { Securities } \\
\text { (2) }\end{array}$ & $\begin{array}{c}\text { Loans } \\
(3)\end{array}$ & $\begin{array}{c}\text { Securities } \\
(4)\end{array}$ & $\begin{array}{c}\text { Loans } \\
(5)\end{array}$ & $\begin{array}{c}\text { Securities } \\
(6)\end{array}$ & $\begin{array}{c}\text { Loans } \\
(7)\end{array}$ & $\begin{array}{c}\text { Securities } \\
(8)\end{array}$ \\
\hline$X_{i}$ & $-0.052 * * *$ & $-0.456 * * *$ & $-0.081 * * *$ & $-0.744 * * *$ & & & $-0.097 * * *$ & $-0.548 * * *$ \\
\hline$X_{H}$ & & & & & $-0.032 * * *$ & $-0.077 * * *$ & & \\
\hline$Y_{H}$ & $0.184 * * *$ & $0.293 * * *$ & $0.091 * * *$ & $0.184 * * *$ & $0.115^{* * *}$ & $0.269 * * *$ & $0.121 * * *$ & $0.224 * * *$ \\
\hline$A_{i}$ & $0.668 * * *$ & $1.001 * * *$ & $0.915 * * *$ & $1.484 * * *$ & $0.787 * * *$ & $0.668 * * *$ & $0.803^{* * *}$ & $1.203 * * *$ \\
\hline$B_{H}$ & $-0.134 * * *$ & $0.064 * * *$ & $-0.087 * * *$ & $0.068 * * *$ & $-0.106 * * *$ & $0.120 * * *$ & $-0.118 * * *$ & $0.127 * * *$ \\
\hline$N_{i}$ & $-0.687 * * *$ & $0.669 * * *$ & $-0.251 * * *$ & 0.0752 & $-0.307 * * *$ & $0.155^{* *}$ & $-0.270 * * *$ & $0.140 \#$ \\
\hline Constant & $16.304 * * *$ & $-6.162 * * *$ & $2.300 * * *$ & $-15.993 * * *$ & $3.833 * * *$ & $-21.198 * * *$ & $2.943 * * *$ & $-14.395 * * *$ \\
\hline Dummies & Bank & Bank & $L / A / S / C$ & $L / A / S / C$ & $L / A / S / C$ & $L / A / S / C$ & $L / A / S / C$ & $L / A / S / C$ \\
\hline Obs. & 24028 & 23658 & 24028 & 23658 & 25948 & 24284 & 20546 & 20546 \\
\hline $\mathrm{R}^{2}$ & 0.534 & 0.152 & 0.454 & 0.141 & 0.397 & 0.0890 & 0.607 & 0.190 \\
\hline Nr. Banks & 5824 & 5834 & & & & & & \\
\hline $\mathrm{F}^{\mathrm{ALL}}$ & 1068 & 128.8 & 872.2 & 68.52 & 623.2 & 37.25 & 545146 & 40201 \\
\hline $\operatorname{Pr}\left(\mathrm{F}^{\mathrm{ALL}}\right)>\mathrm{F}$ & 0 & 0 & 0 & 0 & 0 & 0 & 0 & 0 \\
\hline $\mathrm{F}^{\mathrm{CTRL}}$ & & & 28 & 12.99 & 27.11 & 13.58 & 1629 & 1141 \\
\hline $\operatorname{Pr}\left(\mathrm{F}^{\mathrm{CTRL}}\right)>\mathrm{F}$ & & & 0 & 0 & 0 & 0 & 0 & 0 \\
\hline Hausman & 1292 & 32 & & & & & & \\
\hline $\operatorname{Pr}(\mathrm{H})>\mathrm{chi}^{2}$ & 0 & 0 & & & & & & \\
\hline
\end{tabular}

NOTES: Model 1 consists of equations (1) and (2) in the text. Three hypotheses are tested: substitution effect, size effect, and government neutrality (see Table 1 in the text). All of them are rejected. FE = (bank) fixed effects model with robust standard errors; LAV = least-absolute-value model (Quantile regressions on median) using the HallSheather bandwidth (same results using the Chamberlain bandwidth); IV = Instrumental variables (with robust standard errors). $Y_{i}$ is the dependent variable (i.e. loans or securities). $X_{i}$ is the cross variable, that is securities for the loan equation and loans for the securities equation. $Y_{H}$ and $X_{H}$ is the sum of $Y_{i}$ and $X_{i}$ at the country level. $L=$ listed (dummy); $A$ = accounting standards (dummies); $S=$ specialization (dummies); $C=$ country (dummies). $\mathrm{H}=\mathrm{Hausman}$ test compares fixed vs random effects model using the same specification. (a) both (co)variance matrices base on disturbance variance estimate from efficient estimator because the standard Hausman test is not available. $* * *$ $\mathrm{p}<0.01, * * \mathrm{p}<0.05, * \mathrm{p}<0.10, \# \mathrm{p}<0.15$. 
Table 4: Model 2; panel regressions (Bank FE), quantile regressions (median LAV) and instrumental variables (IV)

\begin{tabular}{|c|c|c|c|c|c|c|c|c|}
\hline \multirow[b]{3}{*}{ Variables } & \multicolumn{8}{|c|}{ Model 2} \\
\hline & \multicolumn{2}{|c|}{$F E$} & \multicolumn{2}{|c|}{$L A V(H S)$} & \multicolumn{2}{|c|}{ LAV - Reduced Form } & \multicolumn{2}{|c|}{$I V$} \\
\hline & $\begin{array}{c}\text { Loans } \\
(1)\end{array}$ & $\begin{array}{c}\text { Securities } \\
\text { (2) }\end{array}$ & $\begin{array}{c}\text { Loans } \\
(3)\end{array}$ & $\begin{array}{c}\text { Securities } \\
(4)\end{array}$ & $\begin{array}{c}\text { Loans } \\
(5)\end{array}$ & $\begin{array}{c}\text { Securities } \\
(6)\end{array}$ & $\begin{array}{c}\text { Loans } \\
(7)\end{array}$ & $\begin{array}{c}\text { Securities } \\
(8)\end{array}$ \\
\hline$X_{i}$ & $-0.055 * * *$ & $-0.482 * * *$ & $-0.080 * * *$ & $-0.735 * * *$ & & & $-0.103 * * *$ & $-0.517 * * *$ \\
\hline$X_{H}$ & & & & & $0.080 * * *$ & 0.098* & & \\
\hline$X B_{H}$ & & & & & $-0.002 * * *$ & $-0.004 * * *$ & & \\
\hline$Y_{H}$ & $0.230 * * *$ & $0.297 * * *$ & $0.122 * * *$ & $0.133 * * *$ & $0.125^{* * *}$ & $0.304 * * *$ & $0.087 * * *$ & -0.0240 \\
\hline$Y B_{H}$ & $-0.001 *$ & 0.0006 & $-0.0004 *$ & $0.001 *$ & -0.0003 & -0.0002 & 0.0004 & $0.004 * * *$ \\
\hline$A_{i}$ & $0.580 * * *$ & $0.783 * * *$ & $0.874 * * *$ & $1.325^{* * *}$ & $0.713 * * *$ & $0.381 * * *$ & $0.716^{* * * *}$ & $0.983 * * *$ \\
\hline$A B_{i}$ & $0.002 * * *$ & $0.004 * * *$ & $0.0005 * * *$ & $0.002 * * *$ & $0.001 * * *$ & $0.004 * * *$ & $0.001 * * *$ & $0.003^{* * *}$ \\
\hline$B_{H}$ & $-0.221 * * *$ & $0.084 * *$ & $-0.162 * * *$ & $0.151 * * *$ & $-0.215 * * *$ & $0.265 * * *$ & $-0.205 * * *$ & $0.238 * * *$ \\
\hline$B_{H}^{2}$ & $0.0003^{* * *}$ & -0.00003 & $0.0003^{* * *}$ & $-0.0003^{* * *}$ & $0.0004 * * *$ & $-0.0006^{* * *}$ & $0.0004 * * *$ & $-0.0004 * * *$ \\
\hline$N_{i}$ & $-0.600 * * *$ & $0.626 * * *$ & $-0.201 * * *$ & 0.0211 & $-0.229 * * *$ & $0.144^{*}$ & $-0.226^{* * *}$ & 0.0975 \\
\hline Constant & $19.808 * * *$ & $-7.949 * * *$ & $3.247 * * *$ & $-15.410^{* * *}$ & $4.701 * * *$ & $-20.284 * * *$ & $5.381 * * *$ & $-11.171^{* * *}$ \\
\hline Dummies & Bank & Bank & $L / A / S / C$ & $L / A / S / C$ & $L / A / S / C$ & $L / A / S / C$ & $L / A / S / C$ & $L / A / S / C$ \\
\hline Obs. & 24028 & 23658 & 24028 & 23658 & 25948 & 24284 & 20546 & 20546 \\
\hline $\mathrm{R}^{2}$ & 0.540 & 0.161 & 0.456 & 0.143 & 0.401 & 0.0970 & 0.610 & 0.196 \\
\hline Nr. Banks & 5824 & 5834 & & & & & & \\
\hline $\mathrm{F}^{\mathrm{ALL}}$ & 809.6 & 139.2 & 942.1 & 86.01 & 705.0 & 50.84 & 346540 & 97473 \\
\hline $\operatorname{Pr}\left(F^{A L L}\right)>F$ & 0 & 0 & 0 & 0 & 0 & 0 & 0 & 0 \\
\hline $\mathrm{F}^{\mathrm{CTRL}}$ & & & 26.76 & 11.63 & 27.18 & 12.43 & 1525 & 826.3 \\
\hline $\operatorname{Pr}\left(\mathrm{F}^{\mathrm{CTRL}}\right)>\mathrm{F}$ & & & 0 & 0 & 0 & 0 & 0 & 0 \\
\hline Hausman & 756.6 & 256.4 & & & & & & \\
\hline $\operatorname{Pr}(\mathrm{H})>\mathrm{chi}^{2}$ & 0 & 0 & & & & & & \\
\hline
\end{tabular}

NOTES: Model 2 consists of equations (3) and (4) in the text. Four hypotheses are tested: substitution effect, size effect, government neutrality, and demand sensitivity to regulator (see Table 1 in the text). The first three are strongly rejected, the fourth is weakly rejected. FE = (bank) fixed effects model with robust standard errors; LAV = leastabsolute-value model (Quantile regressions on median) using the Hall-Sheather bandwidth (same results using the Chamberlain bandwidth); IV = Instrumental variables (with robust SE). $Y_{i}$ is the dependent variable (i.e. loans or securities). $X_{i}$ is the cross variable, that is securities for the loan equation and loans for the securities equation. $Y_{H}$ and $X_{H}$ is the sum of $Y_{i}$ and $X_{i}$ at the country level. $L=$ listed (dummy); $A=$ accounting standards (dummies); $S=$ specialization (dummies); $C=$ country (dummies). $\mathrm{H}=$ Hausman test compares fixed vs random effects model using the same specification. (a) both (co)variance matrices base on disturbance variance estimate from efficient estimator because the standard Hausman test is not available. $* * * \mathrm{p}<0.01, * * \mathrm{p}<0.05, * \mathrm{p}<0.10, \# \mathrm{p}<0.15$. 
Table 5: Model 1 for EU Countries; panel regressions (Bank FE), quantile regressions (median LAV) and instrumental variables (IV)

\begin{tabular}{|c|c|c|c|c|c|c|c|c|}
\hline \multirow[b]{3}{*}{ Variables } & \multicolumn{8}{|c|}{ Model 1} \\
\hline & \multicolumn{2}{|c|}{$F E$} & \multicolumn{2}{|c|}{$L A V(H S)$} & \multicolumn{2}{|c|}{ LAV - Reduced Form } & \multicolumn{2}{|c|}{ IV } \\
\hline & $\begin{array}{l}\text { Loans } \\
\text { (1) }\end{array}$ & $\begin{array}{c}\text { Securities } \\
\text { (2) }\end{array}$ & $\begin{array}{l}\text { Loans } \\
(3)\end{array}$ & $\begin{array}{c}\text { Securities } \\
(4)\end{array}$ & $\begin{array}{c}\text { Loans } \\
(5)\end{array}$ & $\begin{array}{c}\text { Securities } \\
(6)\end{array}$ & $\begin{array}{c}\text { Loans } \\
(7)\end{array}$ & $\begin{array}{c}\text { Securities } \\
(8)\end{array}$ \\
\hline$X_{i}$ & $-0.049 * * *$ & $-0.514 * * *$ & $-0.089^{* * *}$ & $-0.868 * * *$ & & & $-0.157 * * *$ & $-0.964 * * *$ \\
\hline$X_{H}$ & & & & & -0.0107 & $-0.149^{* *}$ & & \\
\hline$Y_{H}$ & $0.251^{* * * *}$ & $0.626^{* * * *}$ & $0.206^{* * *}$ & $0.524 * * *$ & $0.233^{* * *}$ & $0.5589 * * *$ & $0.247^{* * *}$ & $0.543^{* * *}$ \\
\hline$A_{i}$ & $0.592 * * *$ & $1.084 * * *$ & $0.828 * * *$ & $1.656^{* * * *}$ & $0.681 * * *$ & $0.880^{* * *}$ & $0.844 * * *$ & $1.646 * * *$ \\
\hline$B_{H}$ & $-0.345 * * *$ & $0.469^{* * * *}$ & $-0.241 * * *$ & $0.363 * * *$ & $-0.353 * * *$ & $0.546^{* * *}$ & $-0.160 * * *$ & $0.503^{* * *}$ \\
\hline$N_{i}$ & -0.2118 & $0.838^{* * *}$ & $-0.092 * *$ & $0.241 * *$ & $-0.122 * * *$ & $0.257 * *$ & $-0.111 *$ & 0.1762 \\
\hline Constant & $39.763 * * *$ & $-46.359 * * *$ & $17.772 * * *$ & $-17.079 * * *$ & $22.881^{* * * *}$ & $-35.857 * * *$ & 7.6100 & $-28.035^{* * *}$ \\
\hline Dummies & Banks & Banks & $L / A / S / C$ & $L / A / S / C$ & $L / A / S / C$ & $L / A / S / C$ & $L / A / S / C$ & $L / A / S / C$ \\
\hline Obs. & 5576 & 5558 & 5576 & 5558 & 5820 & 5658 & 5228 & 5228 \\
\hline $\mathrm{R}^{2}$ & 0.566 & 0.230 & 0.446 & 0.169 & 0.390 & 0.125 & 0.610 & 0.290 \\
\hline Nr. Banks & 1907 & 1906 & & & & & & \\
\hline $\mathrm{F}^{\mathrm{ALL}}$ & 201.0 & 85.61 & 345.9 & 43.10 & 263.5 & 32.94 & 13215 & 60302 \\
\hline $\operatorname{Pr}\left(\mathrm{F}^{\mathrm{ALL}}\right)>\mathrm{F}$ & 0 & 0 & 0 & 0 & 0 & 0 & 0 & 0 \\
\hline $\mathrm{F}^{\mathrm{CTRL}}$ & & & 10.53 & 8.110 & 19.38 & 10.52 & 151.2 & 219.9 \\
\hline $\operatorname{Pr}\left(\mathrm{F}^{\mathrm{CTRL}}\right)>\mathrm{F}$ & & & 0 & 0 & 0 & 0 & 0 & 0 \\
\hline Hausman & 186.4 & $13.54^{(a)}$ & & & & & & \\
\hline $\operatorname{Pr}(\mathrm{H})>\mathrm{chi}^{2}$ & 0 & 0.0188 & & & & & & \\
\hline
\end{tabular}

NOTES: Model 1 consists of equations (1) and (2) in the text. Three hypotheses are tested: substitution effect, size effect, and government neutrality (see Table 1 in the text). All of them are rejected. FE $=$ (bank) fixed effects model with robust standard errors; LAV = least-absolute-value model (Quantile regressions on median) using the HallSheather bandwidth (same results using the Chamberlain bandwidth); IV = Instrumental variables (with robust SE). $Y_{i}$ is the dependent variable (i.e. loans or securities). $X_{i}$ is the cross variable, that is securities for the loan equation and loans for the securities equation. $Y_{H}$ and $X_{H}$ is the sum of $Y_{i}$ and $X_{i}$ at the country level. $L=$ listed (dummy); $A=$ accounting standards (dummies); $S=$ specialization (dummies); $C=$ country (dummies). $\mathrm{H}=$ Hausman test compares fixed vs random effects model using the same specification. (a) both (co)variance matrices base on disturbance variance estimate from efficient estimator because the standard Hausman test is not available. *** $\mathrm{p}<0.01, * * \mathrm{p}<0.05, * \mathrm{p}<0.10, \# \mathrm{p}<0.15$. 
Table 6: Robustness; panel regressions (Bank FE) and quantile regression (median LAV) with $\mathrm{Y}_{\mathrm{H}}$ and controls

\begin{tabular}{|c|c|c|c|c|c|c|c|c|}
\hline \multirow[b]{3}{*}{ Variables } & \multicolumn{4}{|c|}{ Model 1 (with modified demand) } & \multicolumn{4}{|c|}{ Model 3 (additional controls) } \\
\hline & $F E$ & $F E$ & $L A V$ & $L A V$ & $F E$ & $F E$ & $L A V$ & $L A V$ \\
\hline & $\begin{array}{c}\text { Loans } \\
\text { (1) }\end{array}$ & $\begin{array}{c}\text { Securities } \\
\text { (2) }\end{array}$ & $\begin{array}{l}\text { Loans } \\
(1)\end{array}$ & $\begin{array}{c}\text { Securities } \\
\text { (2) }\end{array}$ & $\begin{array}{c}\text { Loans } \\
\text { (3) }\end{array}$ & $\begin{array}{c}\text { Securities } \\
(4)\end{array}$ & $\begin{array}{c}\text { Loans } \\
(3)\end{array}$ & $\begin{array}{c}\text { Securities } \\
(4)\end{array}$ \\
\hline$X_{i}$ & $-0.050 * * *$ & $-0.393 * * *$ & $-0.081 * * *$ & $-0.713 * * *$ & $-0.055 * * *$ & $-0.655^{* * *}$ & $-0.085^{* * *}$ & $-0.844 * * *$ \\
\hline$Y_{H-1}$ & $0.030 * *$ & $0.018 * *$ & $0.008^{*}$ & $0.009 * * *$ & & & & \\
\hline$Y_{H}$ & & & & & $0.139 * * *$ & $0.275 * * *$ & $0.075 * * *$ & $0.178 * * *$ \\
\hline$A_{i}$ & $0.677 * * *$ & $0.950 * * *$ & $0.930 * * *$ & $1.452 * * *$ & $0.759 * * *$ & $1.251 * * *$ & $0.936 * * *$ & $1.591 * * *$ \\
\hline$B_{H}$ & $-0.142 * * *$ & $0.095^{* * *}$ & $-0.091 * * *$ & $0.076^{* * *}$ & $-0.098 * * *$ & $0.092 * * *$ & $-0.082 * * *$ & $0.081 * * *$ \\
\hline$N_{i}$ & $-0.693 * * *$ & $0.636 * * *$ & $-0.238 * * *$ & 0.0561 & $-0.768 * * *$ & $0.794 * * *$ & $-0.322 * * *$ & 0.084 \\
\hline$E_{i}$ & & & & & $0.435^{* * *}$ & $0.336^{*}$ & $0.083^{* * *}$ & -0.032 \\
\hline$C_{i}$ & & & & & $0.250 * * *$ & & $0.047 * * *$ & \\
\hline$Q_{i}$ & & & & & & $-0.972 * * *$ & & $-0.285^{* * *}$ \\
\hline$D_{i}$ & & & & & $0.627 * * *$ & & $0.154 * * *$ & \\
\hline$R_{i}$ & & & & & & $-1.426 * *$ & & -0.115 \\
\hline Constant & $17.066 * * *$ & $-8.086^{* * *}$ & $3.060 * * *$ & $-14.211 * * *$ & $-60.720 * * *$ & 2.633 & $-15.157 * * *$ & $-8.062 * * *$ \\
\hline Dummies & Banks & Banks & $L / A / S / C$ & $L / A / S / C$ & Banks & Banks & $L / A / S / C$ & $L / A / S / C$ \\
\hline Obs. & 24777 & 24780 & 24777 & 24780 & 21613 & 22332 & 21613 & 22332 \\
\hline $\mathrm{Nr}$ of banks & 5904 & 5905 & & & 5219 & 5590 & & \\
\hline $\mathrm{R}^{2}$ & 0.522 & 0.127 & 0.458 & 0.124 & 0.623 & 0.179 & 0.484 & 0.150 \\
\hline $\mathrm{F}^{\mathrm{ALL}}$ & 924.8 & 64.02 & 852.7 & 66.54 & 1016 & 78.20 & 930.1 & 72.90 \\
\hline $\operatorname{Pr}\left(\mathrm{F}^{\mathrm{ALL}}\right)>\mathrm{F}$ & 0 & 0 & 0 & 0 & 0 & 0 & 0 & 0 \\
\hline $\mathrm{F}^{\mathrm{CTRL}}$ & & & 28.70 & 12.97 & 109.8 & 51.06 & 32.67 & 15.10 \\
\hline $\operatorname{Pr}\left(\mathrm{F}^{\mathrm{CTRL}}\right)>\mathrm{F}$ & & & 0 & 0 & 0 & 0 & 0 & 0 \\
\hline $\mathrm{H}$ & 238.2 & 54 & & & 376.7 & 360.9 & & \\
\hline $\operatorname{Pr}(\mathrm{H})>\operatorname{chi}^{2}$ & 0 & 0 & & & 0 & 0 & & \\
\hline
\end{tabular}

NOTES: Model 3 adds to Model 1 (equations (1) and (2) in the text) a set of controls with continuous common and specific bank variables. Three hypotheses are tested: substitution effect, size effect, and government neutrality (see Table 1 in the text). All of them are rejected. FE = bank fixed effects model with robust standard errors. LAV = leastabsolute-value model (quantile regressions with median) using the Hall-Sheather bandwidth (same results using the Chamberlain bandwidth). $Y_{i}$ is the dependent variable (i.e. loans or securities). $X_{i}$ is the cross variable, that is securities for the loan equation and loans for the securities equation. $Y_{H}$ and $X_{H}$ is the sum of $Y_{i}$ and $X_{i}$ at the country level. $L=$ listed (dummy); $A=$ accounting standards (dummies); $S=$ specialization (dummies); $C=$ country (dummies). $\mathrm{H}=$ Hausman test compares fixed vs random effects model using the same specification. $* * * \mathrm{p}<0.01, * *$ $\mathrm{p}<0.05, * \mathrm{p}<0.10, \# \mathrm{p}<0.15$. 
Table 7: Robustness: IV regressions for Model 1 with additional exogenous variables

\begin{tabular}{|c|c|c|c|c|c|c|c|c|c|c|}
\hline \multirow[b]{2}{*}{ VARIABLES } & \multicolumn{10}{|c|}{ Model $1-I V$} \\
\hline & $\begin{array}{c}\text { Loans } \\
(1)\end{array}$ & $\begin{array}{c}\text { Securities } \\
\text { (2) }\end{array}$ & $\begin{array}{c}\text { Loans } \\
(3)\end{array}$ & $\begin{array}{c}\text { Securities } \\
(4)\end{array}$ & $\begin{array}{c}\text { Loans } \\
(5)\end{array}$ & $\begin{array}{c}\text { Securities } \\
(6)\end{array}$ & $\begin{array}{c}\text { Loans } \\
(7)\end{array}$ & $\begin{array}{c}\text { Securities } \\
(8)\end{array}$ & $\begin{array}{c}\text { Loans } \\
(9)\end{array}$ & $\begin{array}{c}\text { Securities } \\
(10)\end{array}$ \\
\hline$X_{i}$ & $-0.095 * * *$ & $-0.540 * * *$ & $-0.087 * * *$ & $-0.510 * * *$ & $-0.088 * * *$ & $-0.517 * * *$ & $-0.085 * * *$ & $-0.515^{* * *}$ & $-0.092 * * *$ & $-0.529 * * *$ \\
\hline$Y_{H}$ & $0.122 * * *$ & $0.224 * * *$ & $0.123^{* * *}$ & $0.224 * * *$ & $0.123^{* * *}$ & $0.224 * * *$ & $0.123 * * *$ & $0.224 * * *$ & $0.122 * * *$ & $0.223^{* * *}$ \\
\hline$A_{i}$ & $0.801 * * *$ & $1.197 * * *$ & $0.794 * * *$ & $1.175^{* * *}$ & $0.794 * * *$ & $1.180 * * *$ & $0.793 * * *$ & $1.179^{* * *}$ & $0.798 * * *$ & $1.190^{* * *}$ \\
\hline$B_{H}$ & $-0.119 * * *$ & $0.128^{* * *}$ & $-0.120 * * *$ & $0.133^{* * *}$ & $-0.120 * * *$ & $0.132 * * *$ & $-0.121 * * *$ & $0.132 * * *$ & $-0.119 * * *$ & $0.130 * * *$ \\
\hline$N_{i}$ & $-0.268 * * *$ & $0.143 \#$ & $-0.271 * * *$ & $0.152 \#$ & $-0.271 * * *$ & $0.149 \#$ & $-0.272 * * *$ & $0.149 \#$ & $-0.270 * * *$ & $0.145 \#$ \\
\hline Constant & $3.011 * * *$ & $-14.44 * * *$ & $3.135^{* * *}$ & $-14.63 * * *$ & $3.123^{* * *}$ & $-14.583 * * *$ & $3.158 * * *$ & $-14.599 * * *$ & $3.062 * * *$ & $-14.513 * * *$ \\
\hline Dummies & $L / A / S / C$ & $L / A / S / C$ & $L / A / S / C$ & $L / A / S / C$ & $L / A / S / C$ & $L / A / S / C$ & $L / A / S / C$ & $L / A / S / C$ & $L / A / S / C$ & $L / A / S / C$ \\
\hline Observations & 20520 & 20520 & 20519 & 20519 & 20520 & 20520 & 20519 & 20519 & 20518 & 20518 \\
\hline $\mathrm{R}^{2}$ & 0.6068 & 0.1922 & 0.6077 & 0.1914 & 0.6077 & 0.1916 & 0.6080 & 0.1916 & 0.6073 & 0.1920 \\
\hline WALD-Test & 545529 & 40143 & 548380 & 40054 & 548240 & 40078 & 548848 & 40074 & 546817 & 40114 \\
\hline Exog.Vars & E/-/-/- & $E /-/-/-$ & $-/ T /-/-$ & $-/ T /-/-$ & $-/-/ G /-$ & $-/-/ G /-$ & $-/-/-/ M$ & $-/-/-/ M$ & $E / T / G / M$ & $E / T / G / M$ \\
\hline
\end{tabular}

NOTES: Model 1 consists of equations (1) and (2) in the text. Three hypotheses are tested: substitution effect, size effect, and government neutrality (see Table 1 in the text). All of them are rejected. IV regressions with robust standard errors. Exog.Vars = additional exogenous variables at the Step $1 . Y_{i}$ is the dependent variable (i.e. loans or securities). $X_{i}$ is the cross variable, that is securities for the loan equation and loans for the securities equation. $Y_{H}$ and $X_{H}$ is the sum of $Y_{i}$ and $X_{i}$ at the country level. $Y_{H-I}$ is the sum of $Y_{i}$ at the country level except bank $i . L=$ listed (dummy); $A=$ accounting standards (dummies); $S$ $=$ specialization (dummies); $C=$ country (dummies); $E=$ economic growth (\%); $T=$ total business to total assets (\%); $G=$ banks in the business group (unit); $M=$ net interest margin (\%). Results are similar using all combinations of 2 and 3 exogenous controls (not reported for brevity). $* * * \mathrm{p}<0.01, * * \mathrm{p}<0.05, *$ $\mathrm{p}<0.10, \# \mathrm{p}<0.15$. 
Figure 1: Boxplot and frequency distribution after the cleaning procedures: growth rate of gross loans $(\%)$, total securities (\%), and total assets (\%).
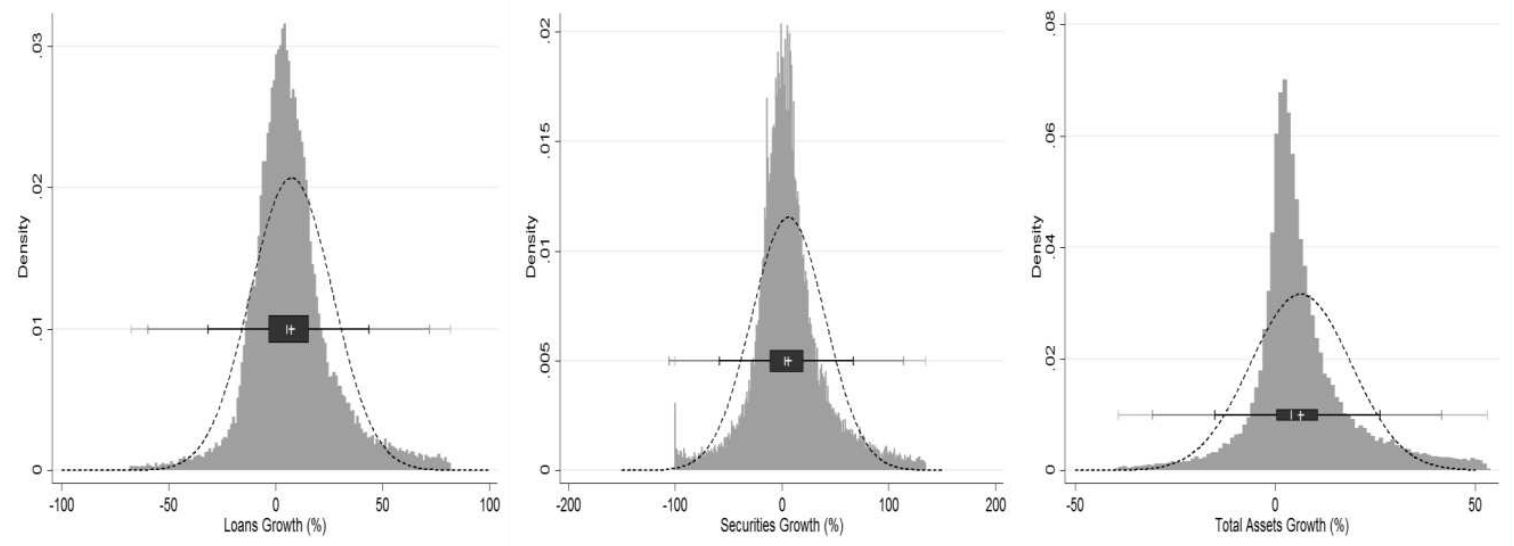

NOTES: Our elaborations on Bankscope data. 
Figure 2: De-leveraging and de-risking: World, Northern and Southern EU countries.

Equity to Total Assets (\%)
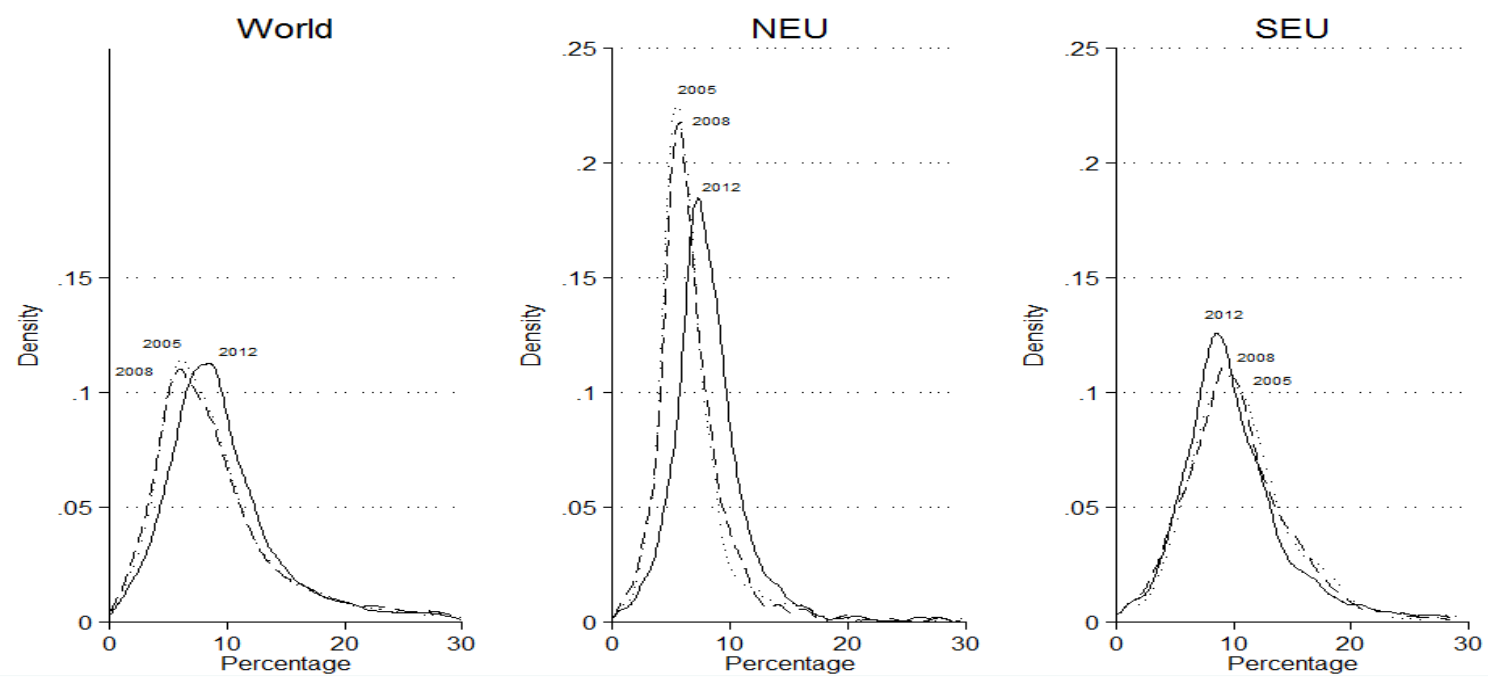

Gross Loans to Total Assets (\%)
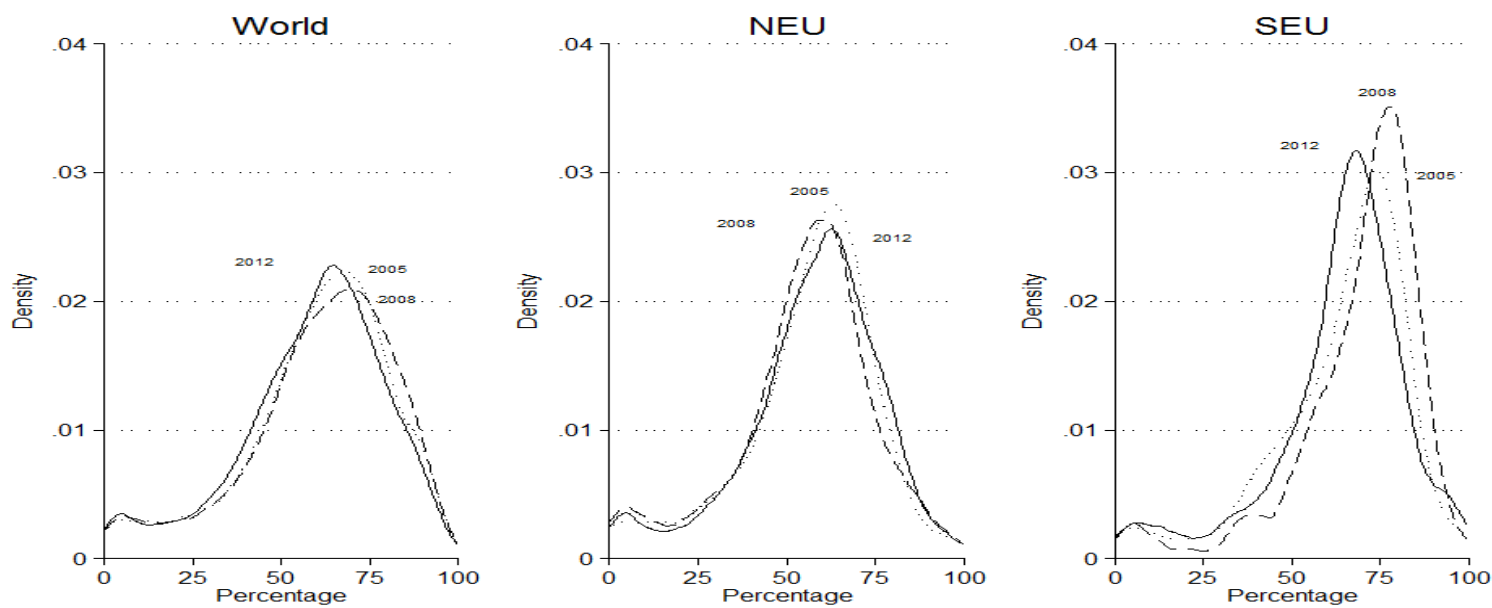

Total Securities to Total Assets (\%)
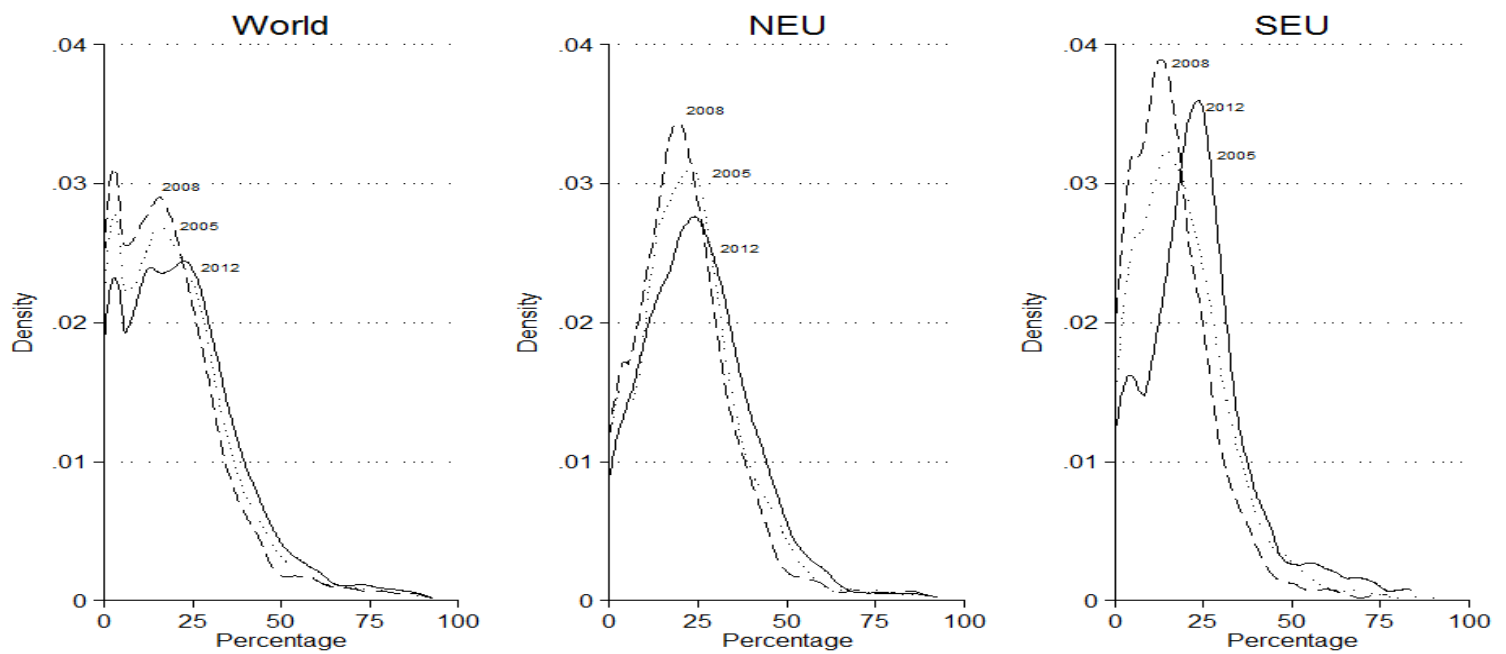

NOTES: Our elaboration on Bankscope data. WORLD = all sample countries, NEU $=$ Northern European Union countries, SEU = Southern European Union countries. 


\section{DATA APPENDIX}

Table A.1: Variable definition and sources.

\begin{tabular}{|c|c|c|}
\hline Variable & Description & Source or Formula \\
\hline Gross Loans & $\begin{array}{l}\text { Total amount of issued credits given to banks } \\
\text { during the accounting period (th. USD) }\end{array}$ & Bankscope \\
\hline Total Securities & $\begin{array}{l}\text { Total amount of securities in bank asset portfolio } \\
\text { (th. USD) }\end{array}$ & Bankscope \\
\hline Total Assets & $\begin{array}{l}\text { Total value of all bank current and long-term assets } \\
\text { (th. USD) }\end{array}$ & Bankscope \\
\hline Total Deposits & $\begin{array}{l}\text { The sum of interest and non-interest bearing deposit } \\
\text { accounts at a bank (th. USD) }\end{array}$ & Bankscope \\
\hline Total Equity & $\begin{array}{l}\text { The total amount of common and preferred } \\
\text { stock equity of the bank (th. USD) }\end{array}$ & Bankscope \\
\hline Liquid Assets & $\begin{array}{l}\text { Cash and central bank reserves of the bank (th. } \\
\text { USD) }\end{array}$ & Bankscope \\
\hline Impaired Loans & $\begin{array}{l}\text { The amount for which it is not likely the bank will } \\
\text { collect the full value of the loans because } \\
\text { the borrowers' creditworthiness is fallen (th. USD) }\end{array}$ & Bankscope \\
\hline$L_{i}$ & $\begin{array}{l}\text { Growth rate in percentage of Gross Loans at the } \\
\text { (individual) bank level (\%) }\end{array}$ & $L_{\mathrm{i}}=\frac{\text { Gross Loans }_{\mathrm{i}, \mathrm{t}}}{\text { Gross Loans }_{\mathrm{i}, \mathrm{t}-1}}-1$ \\
\hline$L_{H}$ & $\begin{array}{l}\text { Growth rate in percentage of Gross Loans at the } \\
\text { (market) country level (\%) }\end{array}$ & $L_{\mathrm{H}}=\frac{\sum_{i \in H} \text { Gross Loans }_{\mathrm{i}, \mathrm{t}}}{\sum_{i \in H} \text { Gross Loans }_{\mathrm{i}, \mathrm{t}-1}}-1$ \\
\hline$S_{i}$ & $\begin{array}{l}\text { Growth rate in percentage of Total Securities at the } \\
\text { (individual) bank level (\%) }\end{array}$ & $S_{\mathrm{i}}=\frac{\text { Total Securities }_{\mathrm{i}, \mathrm{t}}}{\text { Total Securities }_{\mathrm{i}, \mathrm{t}-1}}-1$ \\
\hline$S_{H}$ & $\begin{array}{l}\text { Growth rate in percentage of Total Securities at the } \\
\text { (market) country level }(\%)\end{array}$ & 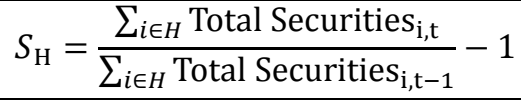 \\
\hline$A_{i}$ & $\begin{array}{l}\text { Growth rate in percentage of Total Assets at the } \\
\text { (individual) bank level (\%) }\end{array}$ & $A_{\mathrm{i}}=\frac{\text { Total }_{\text {Assets }} \text { Total }_{\text {t }}}{\text { Assets }_{\mathrm{i}, \mathrm{t}-1}}-1$ \\
\hline$N_{i}$ & Ratio of Non-Performing Loans to Total Assets (\%) & $N_{\mathrm{i}}=\frac{\text { Impaired Loans }_{\mathrm{i}, \mathrm{t}}}{\text { Total Assets }_{\mathrm{i}, \mathrm{t}}}$ \\
\hline$B_{H}$ & Debt-to-GDP ratio (\%) & World Economic Outlook \\
\hline$E_{i}$ & Ratio of Total Equity to Total Assets (\%) & $E_{\mathrm{i}}=\frac{\text { Total Equity }_{\mathrm{i}, \mathrm{t}}}{\text { Total Assets }}$ \\
\hline$C_{i}$ & Loans-to-deposit coverage ratio (\%) & $N_{\mathrm{i}}=\frac{\text { Impaired Loans }_{\mathrm{i}, \mathrm{t}}}{\text { Total Assets }_{\mathrm{i}, \mathrm{t}}}$ \\
\hline$D_{i}$ & Growth rate of Total Deposits (\%) & $D_{\mathrm{i}}=\frac{\text { Total Deposits }_{\mathrm{i}, \mathrm{t}}}{\text { Total Deposits }}-1$ \\
\hline$Q_{i}$ & Ratio of Liquid Assets to Total Assets (\%) & $Q_{\mathrm{i}}=\frac{{\text { Liquid } \text { Assets }_{\mathrm{i}, \mathrm{t}}}_{\text {Total } \text { Assets }_{\mathrm{i}, \mathrm{t}}}}{\text { Th }}$ \\
\hline$R_{i}$ & Return on Average (Total) Assets (\%) & Bankscope \\
\hline$E$ & Real economic growth rate $(\%)$ & World Economic Outlook \\
\hline$B$ & Ratio of total business to total assets (\%) & Bankscope \\
\hline$G$ & Number of banks in the business group (unit) & Bankscope \\
\hline$M$ & Net interest margin at the bank level (\%) & Bankscope \\
\hline
\end{tabular}


Table A.2: Treatment of outliers on the downloaded variables in level.

\begin{tabular}{|c|c|c|c|c|c|c|}
\hline Varial & & Bankscope & BACON & NEG & IQR & Final \\
\hline \multirow{4}{*}{$\begin{array}{l}\text { Gross } \\
\text { Loans }\end{array}$} & Obs & 81695 & 80530 & 79829 & 70186 & 54331 \\
\hline & Min & -3420.15 & -3420.15 & 0.1 & 0.1 & 0.27 \\
\hline & Max & 3070086000 & 3070086000 & 3070086000 & 7280833 & 7280833 \\
\hline & Mean & 10156189.38 & 6136621.19 & 6190508.56 & 910514.92 & 889380.41 \\
\hline \multirow{4}{*}{$\begin{array}{c}\text { Total } \\
\text { Securities }\end{array}$} & Obs & 80368 & 79203 & 76779 & 67389 & 52720 \\
\hline & Min & -13565.13 & -13565.13 & 0.03 & 0.03 & 0.03 \\
\hline & Max & 3195801331 & 3195801331 & 3195801331 & 2631346.97 & 2631346.97 \\
\hline & Mean & 7990021.14 & 4472523.65 & 4613726.74 & 309709.2 & 311158.64 \\
\hline \multirow{4}{*}{$\begin{array}{l}\text { Total } \\
\text { Assets }\end{array}$} & Obs & 82579 & 81414 & 81414 & 71754 & 55350 \\
\hline & Min & 14.29 & 14.29 & 14.29 & 14.29 & 38.65 \\
\hline & Max & 4682924032 & 4682924032 & 4682924032 & 13882655 & 13882655 \\
\hline & Mean & 22394247.56 & 13386591.24 & 13386591.24 & 1751408.03 & 1691330.07 \\
\hline \multirow{4}{*}{$\begin{array}{l}\text { Impaired } \\
\text { Loans }\end{array}$} & Obs & 48937 & 47772 & 46498 & 41138 & 32757 \\
\hline & Min & -18242.98 & -18242.98 & 0.04 & 0.04 & 0.07 \\
\hline & Max & 251949000 & 251949000 & 251949000 & 339114.89 & 339114.89 \\
\hline & Mean & 515310.57 & 265718.63 & 272999.46 & 39960.35 & 40025.82 \\
\hline \multirow{4}{*}{$\begin{array}{l}\text { Total } \\
\text { Equity }\end{array}$} & Obs & 82574 & 81409 & 81078 & 71882 & 55491 \\
\hline & Min & -136279008 & -136279008 & 0.55 & 0.55 & 7.7 \\
\hline & $\operatorname{Max}$ & 923629888 & 923629888 & 923629888 & 1093172.88 & 1093172.88 \\
\hline & Mean & 1285075.58 & 817295.21 & 840265.08 & 144538.01 & 137490.11 \\
\hline \multirow{4}{*}{$\begin{array}{l}\text { Liquid } \\
\text { Assets }\end{array}$} & Obs & 82322 & 81157 & 81033 & 71424 & 55121 \\
\hline & Min & -1803.25 & -1803.25 & 0.04 & 0.04 & 1 \\
\hline & Max & 1416300800 & 1416300800 & 1416300800 & 1893717.25 & 1893717.25 \\
\hline & Mean & 4979323.99 & 2787035.15 & 2791300.03 & 227780.23 & 223603.8 \\
\hline \multirow{4}{*}{$\begin{array}{c}\text { Total } \\
\text { Deposits }\end{array}$} & Obs & 76554 & 75389 & 74568 & 66171 & 52778 \\
\hline & Min & 0 & 0 & 0.03 & 0.03 & 0.03 \\
\hline & Max & 3399283200 & 3399283200 & 3399283200 & 7397909.5 & 7397909.5 \\
\hline & Mean & 10156573.62 & 5614214.58 & 5676027.56 & 958397.52 & 963833.92 \\
\hline \multirow{4}{*}{$\begin{array}{c}\text { Return on } \\
\text { Assets }\end{array}$} & Obs & 82099 & 80934 & 80934 & 75615 & 58690 \\
\hline & Min & -348.07 & -348.07 & -348.07 & -2.63 & -2.63 \\
\hline & Max & 257.21 & 257.21 & 257.21 & 3.98 & 3.98 \\
\hline & Mean & 0.81 & 0.82 & 0.82 & 0.66 & 0.62 \\
\hline \multirow{2}{*}{ Total } & Obs & 219690 & 218525 & 218525 & 218525 & 160963 \\
\hline & Banks & 21969 & 21968 & 21968 & 21968 & 20236 \\
\hline
\end{tabular}

NOTES: $\mathrm{BACON}=$ blocked adaptive computationally efficient outlier nominators (BACON) algorithm to identify multivariate outliers proposed by Billor, Hadi, and Velleman (2000). A flagged outlier reveals a systematic errors and the whole record is cancelled. NEG = negative values for non-negative defined accounting items. A flagged outlier reveals an idiosyncratic error and its entry is replaced with a missing value. $\mathrm{IQR}=$ outliers identification method based on the interquartile range $I Q$. A point beyond an outer fence is considered an extreme outlier. The lower outer fence is $Q 1-3 * I Q$ where $Q I=$ lower quartile. The higher outer fence is $Q 3+3 * I Q$ where $Q 3=$ upper quartile. Extreme outliers are considered idiosyncratic errors and replaced with missing values. In "Final", we select 6 kinds of banks: bank holdings and holding companies, commercial banks, cooperative banks, investment banks, real estate and mortgage banks, and savings banks. 
Table A.3: Treatment of outliers on the variables transformed in growth rates or ratios.

\begin{tabular}{|c|c|c|c|c|c|}
\hline \multicolumn{2}{|c|}{ Variables } & \multirow{2}{*}{$\begin{array}{r}\text { Growth Rates } \\
59209\end{array}$} & \multirow{2}{*}{$\begin{array}{r}\text { BACON } \\
58979\end{array}$} & \multirow{2}{*}{$\frac{\text { IQR }}{55895}$} & \multirow{2}{*}{$\frac{\text { Final }}{48194}$} \\
\hline \multirow{4}{*}{$\mathrm{L}_{\mathrm{i}}$} & Obs & & & & \\
\hline & Min & -99.99 & -99.99 & -67.51 & -67.51 \\
\hline & Max & 1808766.63 & 1808766.63 & 81.76 & 81.76 \\
\hline & Mean & 122.52 & 120.18 & 7.25 & 7.51 \\
\hline \multirow{4}{*}{$\mathrm{L}_{\mathrm{a}}$} & Obs & 196557 & 196327 & 182879 & 154904 \\
\hline & Min & -99.37 & -99.37 & -42.04 & -37.23 \\
\hline & $\operatorname{Max}$ & 3576.09 & 3576.09 & 41.22 & 41.22 \\
\hline & Mean & 10.26 & 10.21 & -0.61 & 0 \\
\hline \multirow{4}{*}{$\mathrm{S}_{\mathrm{i}}$} & Obs & 56393 & 56163 & 52731 & 45815 \\
\hline & Min & -100 & -100 & -100 & -100 \\
\hline & $\operatorname{Max}$ & 60496568 & 60496568 & 134.57 & 134.57 \\
\hline & Mean & 3422.03 & 3432.95 & 5.52 & 6.11 \\
\hline \multirow{4}{*}{$\mathrm{S}_{\mathrm{a}}$} & Obs & 196557 & 196327 & 181352 & 153972 \\
\hline & Min & -99.16 & -99.16 & -39.26 & -37.56 \\
\hline & $\operatorname{Max}$ & 3007.04 & 3007.04 & 43.09 & 43.09 \\
\hline & Mean & 11.01 & 10.95 & 0.76 & 1.41 \\
\hline \multirow{4}{*}{$\mathrm{A}_{\mathrm{i}}$} & Obs & 75085 & 74855 & 70040 & 54401 \\
\hline & Min & -99.96 & -99.96 & -39.22 & -39.22 \\
\hline & $\operatorname{Max}$ & 980.57 & 980.57 & 53.1 & 53.1 \\
\hline & Mean & 11.62 & 11.59 & 6.42 & 6.43 \\
\hline \multirow{2}{*}{ Total } & Obs & 218525 & 218295 & 218295 & 160963 \\
\hline & Banks & 21968 & 21968 & 21968 & 20236 \\
\hline
\end{tabular}

NOTES: $\mathrm{BACON}=$ blocked adaptive computationally efficient outlier nominators (BACON) algorithm to identify multivariate outliers proposed by Billor, Hadi, and Velleman (2000). A flagged outlier reveals a systematic errors and the whole record is cancelled. IQR $=$ outliers identification method based on the interquartile range $I Q$. A point beyond an outer fence is considered an extreme outlier. The lower outer fence is $Q 1-3 * I Q$ where $Q I=$ lower quartile. The higher outer fence is $Q 3+3 * I Q$ where $Q 3=$ upper quartile. Extreme outliers are considered idiosyncratic errors and replaced with missing values. In "Final", we select 6 kinds of banks: bank holdings and holding companies, commercial banks, cooperative banks, investment banks, real estate and mortgage banks, and savings banks. 
Figure A.1: Boxplot on final data and original data downloaded from Bankscope
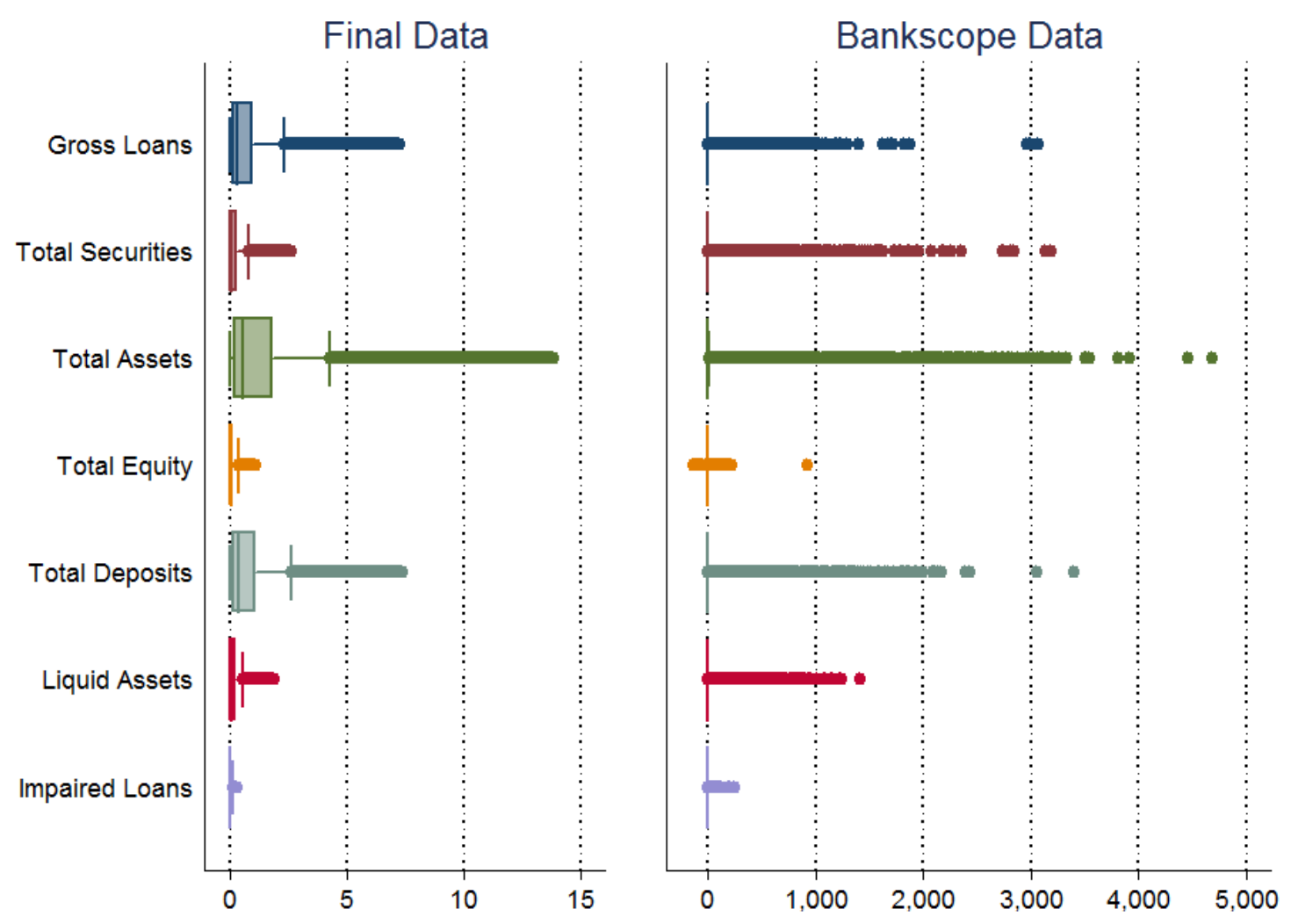

NOTES: The order of magnitude of the $\mathrm{x}$-axis scale on the left (Final Data) is 3 digits smaller than that on the right (Bankscope Data). There is a trade-off between data cleaning and the number of observations. The boxplots on Final Data suggest that the outlier problems could be not completely removed. Stricter cleaning criteria would have reduced excessively the number of observations. 